\title{
Sidereal Ecliptic Coordinate System of Sūryasiddhānta
}

\author{
Raja Ram Mohan Roy* \\ Ryerson University, 350 Victoria St, Toronto, Ontario, Canada M5B 2K3
}

(Received 15 June 2018; revised 17 August 2019)

\begin{abstract}
Indian astronomical texts give the coordinates of the yogatārās or junction stars of nakșatras. These coordinates have been interpreted as polar coordinates, which depend on the position of the north celestial pole. Polar coordinates of a star should change with time due to precession. However, different astronomical texts written over many centuries give same coordinates for most yogatārās. This has resulted in Indian astronomers being called incompetent, who did not observe the positions of the stars with accuracy. In this paper it is proposed that Indian astronomers were using sidereal ecliptic coordinates, which does not change with time to a significant extent. Even though sidereal ecliptic coordinates do not change, order of naksatras was periodically changed to take into account the movement of vernal equinox due to precession. Ecliptic longitudes were updated by simple addition corresponding to the shift in origin of the nakșatra system. It is proposed that a mix up of longitudes from different systems has resulted in a list that obfuscates the true understanding of Indian astronomy. To gain a better understanding of coordinates given in Süryasiddhānta, precise boundaries of nakșatras have been determined based on the yogatārās of Rohin̄i and Krttikā nakșatras. Using the coordinates of the boundaries, the identifications of yogatārās of nakșatras have been reassessed. Among the 28 yogatārās, alternative identifications of six yogatārās have been suggested.
\end{abstract}

Key words: Ecliptic coordinates, Nakșatra, Polar latitude, Polar longitude, Sūryasiddhānta, Yogatārā.

\section{Introduction}

Vedic texts divide the ecliptic in 28 or 27 divisions called nakșatras. Later astronomical texts such as Süryasiddhānta adopted the system of 27 equal divisions. In this system, each naksatra has a span of $13^{\circ} 20^{\prime}$. In addition to the naksatra being a geometrical division of ecliptic spanning over a certain segment of ecliptic, each nakșatra is also characterized by a star or group of stars.

DOI: 10.16943/ijhs/2019/v54i3/49740

*Email: raja.roy@ryerson.ca.
Each nakșatra is also assigned a yogatārā or junction star out of the group of stars belonging to the particular nakșatra. If a nakșatra has only one star in its group, then that star is the yogatārā of that nakșatra. Astronomical text Süryasiddhānta gives the coordinates of each yogatārā.

Burgess (1860) interpreted the coordinates given in Süryasiddhānta as polar coordinates, which is universally accepted. These coordinates depend on the position of the North Celestial Pole, which changes over time due to precession. However, the coordinates given in different astronomical texts are nearly same, even though the texts were written many centuries apart. The change in coordinates 
would have been obvious to the astronomers, if they had the skill to measure the coordinates of the stars. This has resulted in the opinion that Indian astronomers were borrowers from the west and incapable of making accurate astronomical observations. Pingree and Morrissey (1989) write the following about the Indian astronomers:

...that the catalogue of stars found in Paitāmahasiddhānta, which is almost exclusively the basis of the rest of the Indian tradition, since it is at the beginning of the Indian attempts to provide coordinates and uses a coordinate system derived from Greek astronomy, is more likely to be an Indian adaptation of a Greek star catalogue than to be based on observations that were made in India; and that the ineptitude with which Indians historically tried to 'correct' these coordinates militates against any theory that is founded upon the idea that the Indians of medieval period were experts in astronomical observation. ... Our apparent success in finding "identifications" for Lalla's star catalogue, wherein the coordinates are so clearly a mixture of ecliptic and polar values, shows the futility of attaching any credence to them. ...Whichever stars the author of Süryasiddhānta intended to indicate, he was incapable of determining their coordinates accurately, ...It is most astonishing to see an astronomer convert $\lambda^{*}$ into $\lambda$ and call the latter $\lambda^{*}$; even more astonishing is to see him take $\lambda$ to be $\lambda^{*}$, convert it on that assumption into another $\lambda$, and to assert that this wrongly derived $\lambda$ is $\lambda^{*}$ ! There is no excuse for Āryabhața's coordinates... The impression of incompetence does not disappear when we examine our last star catalogue, which Ganeșa incorporated into his Grahalāghava (XI 1-5) in 1520. ...Therefore, either Ganeșa was also incompetent, or he intended to give the coordinates of a different set of stars. ... We must conclude from this survey that the Indians did not observe the positions of the stars with accuracy; by implication, they also did not observe those of the planets with accuracy.

It is obvious that the interpretation of coordinates given in Indian astronomical texts as polar coordinates has resulted in Indian astronomers being called incompetent. In this paper it is proposed that the coordinates of yo- gatārās given in the Indian astronomical texts are ecliptic coordinates and since these coordinates don't change appreciably over time in a sidereal ecliptic coordinate system, Indian astronomers relied on the coordinates received from earlier astronomers. To account for precession, Indian astronomers changed the origin of the nakșatra system periodically. The coordinates were updated to reflect the new origin of the nakșatra system by adding the appropriate amount to ecliptic longitudes. With this insight, the coordinates of yogatārās given in Süryasiddhānta have been compared to the coordinates of yogatārās identified by Burgess (1860) and new identifications of some yogatārās have been proposed. In addition, the exact boundary of each nakșatra has been determined.

\section{Textual information}

The coordinates of yogatārās given in Sūryasiddhānta are shown in Table 1. Three different translations of Sūryasiddhānta were consulted, Burgess (1860) in English, Śrīvāstava (1982) in Hindi and Siṃha (1986) in Hindi. All translations provide identical information regarding the raw data given in Sūryasiddhānta and how the data is to be interpreted. The longitude data is given indirectly using a term "svabhoga". Instead of giving svabhoga values, one tenth of these values are given as shown in the column "Data" in Table 1. After multiplying by ten, these values yield svabhoga in arcminutes, which is then converted to degree and arcminutes as shown under the column "svabhoga" in Table 1. Svabhoga represents the relative longitude and is to be added to the longitude of the beginning of the respective nakșatra to obtain the longitude of the given yogatārā.

The list of nakșatras begins with Aśvinī and ends with Revatī. Since Süryasiddhānta follows the system of 27 equal divisions of the ecliptic, each nakșatra has a span of $13^{\circ} 20^{\prime}$. The beginning and end points of each nakșatra can then be calculated as shown under the column "Span". Adding relative longitude to the longitude of the beginning point of respective nakșatra yields the longitude of the yogatārā and is called dhruvaka in Süryasiddhānta. The calculated values of dhruvaka are shown in the column "Dhruvaka" in Table 1.

Süryasiddhānta calls the latitude vikșepa and gives the value and direction relative to ecliptic directly as shown in 
Table 1 The coordinate of yogatārās according to Sūryasiddhānta 8.1-9 Burges (1860), Śrīvāstava (1982), Siṃha (1986).

\begin{tabular}{|c|c|c|c|c|c|c|c|}
\hline \multirow[t]{2}{*}{ No. } & \multirow{2}{*}{$\begin{array}{l}\text { Nakșatra } \\
\text { yogatārā }\end{array}$} & \multicolumn{3}{|c|}{$\begin{array}{c}\text { Svabhoga } \\
\text { (relative longitude) }\end{array}$} & \multirow{2}{*}{$\begin{array}{c}\text { Span } \\
\text { Deg.-min. }\end{array}$} & \multirow{2}{*}{$\begin{array}{c}\begin{array}{c}\text { Dhruvaka } \\
\text { (longitude) }\end{array} \\
\text { Deg.-min. }\end{array}$} & \multirow{2}{*}{$\begin{array}{c}\begin{array}{c}\text { Vikșepa } \\
\text { (latitude) }\end{array} \\
\text { Deg.-min. }\end{array}$} \\
\hline & & Data & Arc min. & Deg.-min. & & & \\
\hline 1 & Aśvin̄̄ & 48 & 480 & $8^{\circ} 0^{\prime}$ & $0^{\circ} 0^{\prime}-13^{\circ} 20^{\prime}$ & $8^{\circ} 0^{\prime}$ & $10^{\circ} 0^{\prime} \mathrm{N}$ \\
\hline 2 & Bharaṇi & 40 & 400 & $6^{\circ} 40^{\prime}$ & $13^{\circ} 20^{\prime}-26^{\circ} 40^{\prime}$ & $20^{\circ} 0^{\prime}$ & $12^{\circ} 0^{\prime} \mathrm{N}$ \\
\hline 3 & Krttikā & 65 & 650 & $10^{\circ} 50^{\prime}$ & $26^{\circ} 40^{\prime}-40^{\circ} 0^{\prime}$ & $37^{\circ} 30^{\prime}$ & $5^{\circ} 0^{\prime} \mathrm{N}$ \\
\hline 4 & Rohiṇ̄̄ & 57 & 570 & $9^{\circ} 30^{\prime}$ & $40^{\circ} 0^{\prime}-53^{\circ} 20^{\prime}$ & $49^{\circ} 30^{\prime}$ & $5^{\circ} 0^{\prime} \mathrm{S}$ \\
\hline 5 & Mrgaśirā & 58 & 580 & $9^{\circ} 40^{\prime}$ & $53^{\circ} 20^{\prime}-66^{\circ} 40^{\prime}$ & $63^{\circ} 0^{\prime}$ & $10^{\circ} 0^{\prime} \mathrm{S}$ \\
\hline 6 & $\bar{A} r d r \bar{a}$ & 4 & 40 & $0^{\circ} 40^{\prime}$ & $66^{\circ} 40^{\prime}-80^{\circ} 0^{\prime}$ & $67^{\circ} 20^{\prime}$ & $0^{\circ} 0^{\prime} \mathrm{S}$ \\
\hline 7 & Punarvasu & 78 & 780 & $13^{\circ} 0^{\prime}$ & $80^{\circ} 0^{\prime}-93^{\circ} 20^{\prime}$ & $93^{\circ} 0^{\prime}$ & $6^{\circ} 0^{\prime} \mathrm{N}$ \\
\hline 8 & Pușya & 76 & 760 & $12^{\circ} 40^{\prime}$ & $93^{\circ} 20^{\prime}-106^{\circ} 40^{\prime}$ & $106^{\circ} 0^{\prime}$ & $0^{\circ} 0^{\prime}$ \\
\hline 9 & $\bar{A}$ śleșā & 14 & 140 & $2^{\circ} 20^{\prime}$ & $106^{\circ} 40^{\prime}-120^{\circ} 0^{\prime}$ & $109^{\circ} 0^{\prime}$ & $7^{\circ} 0^{\prime} \mathrm{S}$ \\
\hline 10 & Maghā & 54 & 540 & $9^{\circ} 0^{\prime}$ & $120^{\circ} 0^{\prime}-133^{\circ} 20^{\prime}$ & $129^{\circ} 0^{\prime}$ & $0^{\circ} 0^{\prime}$ \\
\hline 11 & $\begin{array}{l}\text { Pūrva- } \\
\text { phālgunī }\end{array}$ & 64 & 640 & $10^{\circ} 40^{\prime}$ & $133^{\circ} 20^{\prime}-146^{\circ} 40^{\prime}$ & $144^{\circ} 0^{\prime}$ & $12^{\circ} 0^{\prime} \mathrm{N}$ \\
\hline 12 & $\begin{array}{l}\text { Uttara- } \\
\text { phālgunī }\end{array}$ & 50 & 500 & $8^{\circ} 20^{\prime}$ & $146^{\circ} 40^{\prime}-160^{\circ} 0^{\prime}$ & $155^{\circ} 0^{\prime}$ & $13^{\circ} 0^{\prime} \mathrm{N}$ \\
\hline 13 & Hasta & 60 & 600 & $10^{\circ} 0^{\prime}$ & $160^{\circ} 0^{\prime}-173^{\circ} 20^{\prime}$ & $170^{\circ} 0^{\prime}$ & $11^{\circ} 0^{\prime} \mathrm{S}$ \\
\hline 14 & Citrā & 40 & 400 & $6^{\circ} 40^{\prime}$ & $173^{\circ} 20^{\prime}-186^{\circ} 40^{\prime}$ & $180^{\circ} 0^{\prime}$ & $2^{\circ} 0^{\prime} \mathrm{S}$ \\
\hline 15 & Swāti & 74 & 740 & $12^{\circ} 20^{\prime}$ & $186^{\circ} 40^{\prime}-200^{\circ} 0^{\prime}$ & $199^{\circ} 0^{\prime}$ & $37^{\circ} 0^{\prime} \mathrm{N}$ \\
\hline 16 & Viśākhā & 78 & 780 & $13^{\circ} 0^{\prime}$ & $200^{\circ} 0^{\prime}-213^{\circ} 20^{\prime}$ & $213^{\circ} 0^{\prime}$ & $1^{\circ} 30^{\prime} \mathrm{S}$ \\
\hline 17 & Anurādhā & 64 & 640 & $10^{\circ} 40^{\prime}$ & $213^{\circ} 20^{\prime}-226^{\circ} 40^{\prime}$ & $224^{\circ} 0^{\prime}$ & $3^{\circ} 0^{\prime} \mathrm{S}$ \\
\hline 18 & Jyeșthā & 14 & 140 & $2^{\circ} 20^{\prime}$ & $226^{\circ} 40^{\prime}-240^{\circ} 0^{\prime}$ & $229^{\circ} 0^{\prime}$ & $4^{\circ} 0^{\prime} \mathrm{S}$ \\
\hline 19 & Mūla & 6 & 60 & $1^{\circ} 0^{\prime}$ & $240^{\circ} 0^{\prime}-253^{\circ} 20^{\prime}$ & $241^{\circ} 0^{\prime}$ & $9^{\circ} 0^{\prime} \mathrm{S}$ \\
\hline 20 & Pūrvāṣā & 4 & 40 & $0^{\circ} 40^{\prime}$ & $253^{\circ} 20^{\prime}-266^{\circ} 40^{\prime}$ & $254^{\circ} 0^{\prime}$ & $5^{\circ} 30^{\prime} \mathrm{S}$ \\
\hline 21 & Uttarāṣā & \multicolumn{3}{|c|}{ at the middle of $P \bar{u} r v \bar{a} s ̦ \bar{a} d h \bar{a}$} & $266^{\circ} 40^{\prime}-280^{\circ} 0^{\prime}$ & $260^{\circ} 0^{\prime}$ & $5^{\circ} 30^{\prime} \mathrm{S}$ \\
\hline 22 & Abhijīt & \multicolumn{3}{|c|}{ at the end of $P \bar{u} r v \bar{a} s \underline{a} \bar{d} h \bar{a}$} & None & $266^{\circ} 40^{\prime}$ & $60^{\circ} 0^{\prime} \mathrm{N}$ \\
\hline 23 & Śravaṇa & \multicolumn{3}{|c|}{ at the end of Uttarāṣa $\bar{a} h h \bar{a}$} & $280^{\circ} 0^{\prime}-293^{\circ} 20^{\prime}$ & $280^{\circ} 0^{\prime}$ & $30^{\circ} 0^{\prime} \mathrm{N}$ \\
\hline 24 & Dhanișthā & \multicolumn{3}{|c|}{$\begin{array}{l}\text { At the junction of 3rd and 4th } \\
\text { quarter of Śravaṇa }\end{array}$} & $293^{\circ} 20^{\prime}-306^{\circ} 40^{\prime}$ & $290^{\circ} 0^{\prime}$ & $36^{\circ} 0^{\prime} \mathrm{N}$ \\
\hline 25 & Śatabhișaja & 80 & 800 & $13^{\circ} 20^{\prime}$ & $306^{\circ} 40^{\prime}-320^{\circ} 0^{\prime}$ & $320^{\circ} 0^{\prime}$ & $0^{\circ} 30^{\prime} \mathrm{S}$ \\
\hline 26 & $\begin{array}{l}\text { Pūrva- } \\
\text { bhādrapadā }\end{array}$ & 36 & 360 & $6^{\circ} 0^{\prime}$ & $320^{\circ} 0^{\prime}-333^{\circ} 20^{\prime}$ & $326^{\circ} 0^{\prime}$ & $24^{\circ} 0^{\prime} \mathrm{N}$ \\
\hline 27 & $\begin{array}{l}\text { Uttara- } \\
\text { bhādrapadā }\end{array}$ & 22 & 220 & $3^{\circ} 40^{\prime}$ & $333^{\circ} 20^{\prime}-346^{\circ} 40^{\prime}$ & $337^{\circ} 0^{\prime}$ & $26^{\circ} 0^{\prime} \mathrm{N}$ \\
\hline 28 & Revatī & 79 & 790 & $13^{\circ} 10^{\prime}$ & $346^{\circ} 40^{\prime}-360^{\circ} 0^{\prime}$ & $359^{\circ} 50^{\prime}$ & $0^{\circ} 0^{\prime}$ \\
\hline
\end{tabular}


the column "Vikșepa" in Table 1. Dhruvaka and vikșepa are universally translated as polar longitude and polar latitude respectively. Since this interpretation is contested in this paper, dhruvaka and viksepa are translated simply as longitude and latitude respectively in Table 1. After Uttarāsāạhā nakṣatra (at number 21 in the list), Abhijīt nakșatra is listed, but no span is given to this nakṣatra. Abhijīt nakșatra was part of 28 nakṣatra system, but was dropped from the list in 27 nakșatra system, and hence has no span in this system. The longitudes of the yogatārās of Uttarāṣā nakșatras are given differently in terms of their positions relative to other nakșatras as shown in Table 1. The yogatārās of Uttarāṣā span of their respective nakșatras.

\section{Polar longitude and latitude}

It is currently accepted that the coordinates of yogatārās given in Sūryasiddhānta are in terms of polar longitudes and latitudes. The terms polar longitude and polar latitude were coined by Burgess (1860) in his translation of Sūryasiddhānta, which uses the term dhruvaka for longitude and vikșepa for latitude. Burgess has identified dhruvaka and vikșepa as polar longitude and polar latitude respectively. The concept of polar coordinates of stars as illustrated by Burgess (1860) is shown in Figure 1. To determine the polar longitude and latitude of a star ( $\mathrm{S}$ or $S^{\prime}$ ), a segment of circle of declination (PSca or $P c^{\prime} a^{\prime} S$ ) is drawn from North Celestial Pole (P) passing through the star up to the ecliptic. Polar latitude is the angular distance of the star (Sa or $S^{\prime} a^{\prime}$ ) from the ecliptic along the circle of declination. Polar longitude is the angular distance (La or $\mathrm{L} a^{\prime}$ ) from reference point (L) on the ecliptic and the point of intersection of the ecliptic with the circle of declination passing through the star (a or $a^{\prime}$ ). Burgess (1860) has shown ecliptic below the celestial equator in the illustration, which is wrong. For point L to denote vernal equinox, ecliptic should be shown above the celestial equator in Figure 1.

It should be noted that this whole geometrical construction for determining polar longitude and latitude is very artificial. In ecliptic coordinate system, ecliptic latitudes are determined by measuring angular distances from ecliptic along the great circle passing through the North Ecliptic Pole. In celestial coordinate system,

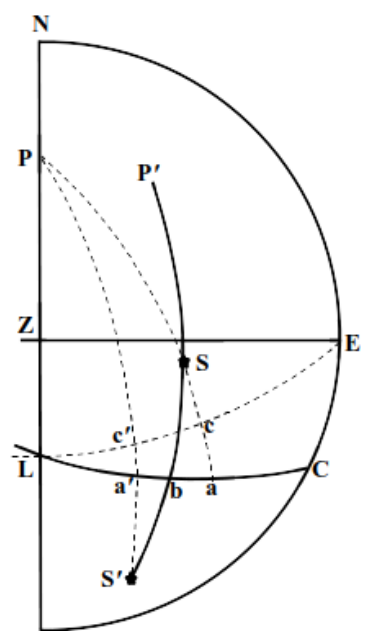

Lc'cE: Celestial Equator

La'baC: Ecliptic

P: North Celestial Pole

P': North Ecliptic Pole

S: Position of a star north of ecliptic

S': Position of a star south of ecliptic

PSca, $\mathrm{Pc}^{\prime} \mathrm{a}^{\prime} \mathrm{S}^{\prime}$ : Circles of declination

Lc, Lc': Right ascensions

Sc, $S^{\prime} c^{\prime}$ : Declinations

Lb: Ecliptic longitude

Sb, S'b: Ecliptic latitude

$\mathrm{La}, \mathrm{La}^{\prime}$ : Polar longitudes

Sa, $\mathrm{S}^{\prime} \mathrm{a}^{\prime}$ : Polar latitudes

Figure 1 Illustration of polar longitude and latitude of stars by Burgess (1860).

declinations are determined by measuring angular distances from celestial equator along the great circle passing through the North Celestial Pole.

In every coordinate system, the latitude is measured respective to the corresponding pole. In the artificial construct of polar latitude, the angular distance is measured from the ecliptic along the great circle that does not pass through the pole of ecliptic (North Ecliptic Pole), but passes through North Celestial Pole instead. Burgess has justified this artificial construction by taking the meaning of Dhruvaka as pertaining to Dhruva or pole star, and therefore he has drawn great circle passing through North Celestial Pole. In accordance with Dhruvaka, Burgess has postulated that vikṣepa means polar latitude. There is absolutely nothing in any astronomical text that describes this method of measuring longitude and latitude. The term vikṣepa has been used many times in Sūryasiddhānta such as in 2.6, 2.63 and 7.7, and in all these places vikṣepa has not been interpreted as polar latitude even by Burgess (1960). It will be odd for the same text (Sūryasiddhānta) to use two different coordinate systems (ecliptic and polar) without providing any explanation. Moreover, Dhruva also means fixed or not moving and thus Dhruvaka simply means fixed longitude. Many Indian astronomers such as Bhāskara in Mahābhāskarīya (III. 62-71) refer to the coordinates of yogatārās as ecliptic longitude and latitude as described by Pingree and Morrissey (1989): 
What is remarkable about Bhāskara's ecliptic coordinates is that, in most cases, they are within $1^{\circ}$ of the Paitāmaha's polar coordinates; this is the case for the longitudes of nos. $1,4,5,8,10,12,16,18$, 19 , and 28 , and for the latitudes of nos. $1,2,3,4$, $5,6,7,8,9,10,11,12,15,16,17,18,19,23,24,25$, 26,27 , and 28 - that is, for 33 out of 54 possibilities. This fact denies to Bhāskara the possibility of his having himself made independent observations, or of his having used a source based on independent observations. This lack of observational input is emphasized by the fact that his changes of the Paitāmaha's coordinates lead either to worse results or to dimmer stars or to both.

It is surprising that despite the emphatic declaration by Indian astronomers that they were using ecliptic coordinates, no one has challenged the prevailing view that Indian astronomers were using polar coordinates. First, the information provided by Indian astronomers has been incorrectly interpreted and then that false interpretation has been used to claim that Indian astronomers were inept and did not know how to measure the positions of stars and planets. If that is the case, then correct framework needs to be developed in which the coordinates given by Indian astronomers make better sense and currently accepted identifications of yogatārās need to be reassessed to check if other stars fit the given coordinates better.

\section{Currently accepted identifications of yogatārās}

Based on his assumption that coordinates given in Sūryasiddhānta are polar longitudes and latitudes, Burgess (1860) identified the yogatārās as shown in Table 2. These identifications are currently accepted by most scholars. For comparative purpose, ecliptic coordinates (J2000.0) of these yogatārās are also given in Table 2 along with the coordinates (dhruvaka and vikșepa) given in Sūryasiddhānta (8.1-9). The data for ecliptic coordinates (J2000.0) were obtained using Stellarium software by setting the date to January 1, 2000 at 12:00 noon and noting the ecliptic longitudes and latitudes by selecting the specific stars. With the tabulation of currently accepted identifications of yogatārās and their ecliptic coordinates, these identifications can be reassessed to check if other stars fit the description in the astronomical texts better. For this purpose, a precise determination of the boundaries of nakșatras is required.

\section{Determination of nakșatra boundaries}

Figure 2 illustrates the principle of the division of celestial sphere in nakșatra zones. $K$ and $K^{\prime}$ represent north ecliptic pole and south ecliptic pole respectively. A, B, C, and $\mathrm{D}$ are the boundaries of nakșatras on the ecliptic. In a 27 nakșatra system, there will be 27 such points on the ecliptic through which the boundaries of nakșatras will pass. As the nakșatras have equal span in the 27 naksatra system according to Sūryasiddhānta 2.64, each nakșatra has a span of $13^{\circ} 20^{\prime}$ on the ecliptic. Each nakșatra zone comprises of the area bound by two great semi-circles passing through $K$ and $K^{\prime}$ and through its boundaries on the ecliptic such as $K A K^{\prime} B K, K B K^{\prime} C K, K C K^{\prime} D K$, and so on. It is expected that the yogatārā and stars belonging to a nakșatra will fall in its nakșatra zone. It should be noted that in the ancient Indian system it was not necessary for the yogatārā and stars belonging to a nakșatra to fall within the zodiac, which is a region spanning $8^{\circ}$ on both side of the ecliptic.

Though later astronomical texts divide the celestial sphere in 27 nakșatras, earlier texts also describe a system consisting of 28 nakșatra. It takes the moon 27.32 days to return to the same position among the stars. Based on the observation that the sidereal month is more than 27 days but less than 28 days, the path of moon in the background of the stars was divided in 28 or 27 divisions. Atharvaveda Samhitā (19.7.1-5) lists 28 nakṣatras beginning with Krttikā and ending in Bharaṇi Taittirīya Saṃhitā (iv.4.10) and Taittirīya Brāhmaṇa (1.5.2.7) list 27 nakșatra beginning with Krttikā and ending in Bharaṇi. Nakṣatra Abhijìt is part of the list of 28 nakșatras, but is dropped from the list in the system of 27 nakșatras. There is a dialogue between gods Indra and Skanda regarding the dropping of nakșatra Abhijīt in Mahābhārata (Vana Parva, Chapter 230, verses 8-10). In this dialogue, Indra says to Skanda that because of jealousy with Rohin̄i, her younger sister Abhijīt has gone to forest to do penance. Indra further says that Brahmā had fixed the counting of time from the beginning of Dhaniștha $\bar{a}$ and earlier Rohin̄i was first. This story tells 
Table 2 Identification of yogatārās by Burgess (1860).

\begin{tabular}{|c|c|c|c|c|c|c|}
\hline No. & Nakṣatra & $\begin{array}{c}\text { Junction-star } \\
(\text { yogatārāa) }\end{array}$ & $\begin{array}{c}\text { Ecliptic } \\
\text { longitude }^{b}\end{array}$ & $\begin{array}{c}\text { Dhruvaka } \\
\text { (longitude) }\end{array}$ & $\begin{array}{l}\text { Ecliptic } \\
\text { latitude }^{b}\end{array}$ & $\begin{array}{c}\text { vikșepa } \\
\text { (latitude) }\end{array}$ \\
\hline 1 & Aśvinī & $\beta$ Ari & $33^{\circ} 58^{\prime}$ & $8^{\circ} 0^{\prime}$ & $8^{\circ} 29^{\prime} \mathrm{N}$ & $10^{\circ} 0^{\prime} \mathrm{N}$ \\
\hline 2 & Bharaṇ̄ & 35 Ari & $46^{\circ} 56^{\prime}$ & $20^{\circ} 0^{\prime}$ & $11^{\circ} 19^{\prime} \mathrm{N}$ & $12^{\circ} 0^{\prime} \mathrm{N}$ \\
\hline 3 & Krttikā & $\eta$ Tau & $60^{\circ} 00^{\prime}$ & $37^{\circ} 30^{\prime}$ & $4^{\circ} 03^{\prime} \mathrm{N}$ & $5^{\circ} 0^{\prime} \mathrm{N}$ \\
\hline 4 & Rohiṇ̄ & $\alpha \mathrm{Tau}$ & $69^{\circ} 47^{\prime}$ & $49^{\circ} 30^{\prime}$ & $5^{\circ} 28^{\prime} \mathrm{S}$ & $5^{\circ} 0^{\prime} \mathrm{S}$ \\
\hline 5 & Mrgaśirā & $\lambda$ Ori & $83^{\circ} 42^{\prime}$ & $63^{\circ} 0^{\prime}$ & $13^{\circ} 22^{\prime} \mathrm{S}$ & $10^{\circ} 0^{\prime} \mathrm{S}$ \\
\hline 6 & $\bar{A} r d r \bar{a}$ & $\alpha$ Ori & $88^{\circ} 45^{\prime}$ & $67^{\circ} 20^{\prime}$ & $16^{\circ} 02^{\prime} \mathrm{S}$ & $9^{\circ} 0^{\prime} \mathrm{S}$ \\
\hline 7 & Punarvasu & $\beta \mathrm{Gem}$ & $113^{\circ} 13^{\prime}$ & $93^{\circ} 0^{\prime}$ & $6^{\circ} 41^{\prime} \mathrm{N}$ & $6^{\circ} 0^{\prime} \mathrm{N}$ \\
\hline 8 & Puṣya & $\delta \mathrm{Cnc}$ & $128^{\circ} 43^{\prime}$ & $106^{\circ} 0^{\prime}$ & $0^{\circ} 05^{\prime} \mathrm{N}$ & $0^{\circ} 0^{\prime}$ \\
\hline 9 & Áśleșāu & $\epsilon$ Hya & $132^{\circ} 21^{\prime}$ & $109^{\circ} 0^{\prime}$ & $11^{\circ} 06^{\prime} \mathrm{S}$ & $7^{\circ} 0^{\prime} \mathrm{S}$ \\
\hline 10 & Maghā & $\alpha$ Leo & $149^{\circ} 50^{\prime}$ & $129^{\circ} 0^{\prime}$ & $0^{\circ} 28^{\prime} \mathrm{N}$ & $0^{\circ} 0^{\prime}$ \\
\hline 11 & $\begin{array}{l}\text { Pūrva- } \\
\text { phālgunī }\end{array}$ & $\delta$ Leo & $161^{\circ} 19^{\prime}$ & $144^{\circ} 0^{\prime}$ & $14^{\circ} 20^{\prime} \mathrm{N}$ & $12^{\circ} 0^{\prime} \mathrm{N}$ \\
\hline 12 & $\begin{array}{l}\text { Uttara- } \\
\text { phālgunī }\end{array}$ & $\beta$ Leo & $171^{\circ} 37^{\prime}$ & $155^{\circ} 0^{\prime}$ & $12^{\circ} 16^{\prime} \mathrm{N}$ & $13^{\circ} 0^{\prime} \mathrm{N}$ \\
\hline 13 & Hasta & $\delta \mathrm{Crv}$ & $193^{\circ} 27^{\prime}$ & $170^{\circ} 0^{\prime}$ & $12^{\circ} 12^{\prime} \mathrm{S}$ & $11^{\circ} 0^{\prime} \mathrm{S}$ \\
\hline 14 & Citrā & $\alpha \operatorname{Vir}$ & $203^{\circ} 50^{\prime}$ & $180^{\circ} 0^{\prime}$ & $2^{\circ} 03^{\prime} \mathrm{S}$ & $2^{\circ} 0^{\prime} \mathrm{S}$ \\
\hline 15 & Swāti & $\alpha$ Boo & $204^{\circ} 14^{\prime}$ & $199^{\circ} 0^{\prime}$ & $30^{\circ} 44^{\prime} \mathrm{N}$ & $37^{\circ} 0^{\prime} \mathrm{N}$ \\
\hline 16 & Viśākhā & $\iota \mathrm{Lib}$ & $231^{\circ} 00^{\prime}$ & $213^{\circ} 0^{\prime}$ & $1^{\circ} 51^{\prime} \mathrm{S}$ & $1^{\circ} 30^{\prime} \mathrm{S}$ \\
\hline 17 & Anurādhā & $\delta \mathrm{Sco}$ & $242^{\circ} 34^{\prime}$ & $224^{\circ} 0^{\prime}$ & $1^{\circ} 59^{\prime} \mathrm{S}$ & $3^{\circ} 0^{\prime} \mathrm{S}$ \\
\hline 18 & Jyeșthā & $\delta$ Sco & $249^{\circ} 46^{\prime}$ & $229^{\circ} 0^{\prime}$ & $4^{\circ} 34^{\prime} \mathrm{S}$ & $4^{\circ} 0^{\prime} \mathrm{S}$ \\
\hline 19 & Mūla & $\lambda \mathrm{Sco}$ & $264^{\circ} 35^{\prime}$ & $241^{\circ} 0^{\prime}$ & $13^{\circ} 47^{\prime} \mathrm{S}$ & $9^{\circ} 0^{\prime} \mathrm{S}$ \\
\hline 20 & Pūrvāṣā & $\delta \mathrm{Sgr}$ & $274^{\circ} 35^{\prime}$ & $254^{\circ} 0^{\prime}$ & $6^{\circ} 28^{\prime} \mathrm{S}$ & $5^{\circ} 30^{\prime} \mathrm{S}$ \\
\hline 21 & Uttarāṣā & $\sigma \mathrm{Sgr}$ & $282^{\circ} 23^{\prime}$ & $260^{\circ} 0^{\prime}$ & $3^{\circ} 27^{\prime} \mathrm{S}$ & $5^{\circ} 0^{\prime} \mathrm{S}$ \\
\hline 22 & Abhijìt & $\alpha \operatorname{Lyr}$ & $285^{\circ} 19^{\prime}$ & $266^{\circ} 40^{\prime}$ & $61^{\circ} 44^{\prime} \mathrm{N}$ & $60^{\circ} 0^{\prime} \mathrm{N}$ \\
\hline 23 & Śravaṇa & $\alpha \mathrm{Aql}$ & $301^{\circ} 47^{\prime}$ & $280^{\circ} 0^{\prime}$ & $29^{\circ} 18^{\prime} \mathrm{N}$ & $30^{\circ} 0^{\prime} \mathrm{N}$ \\
\hline 24 & Dhanișthā & $\beta$ Del & $316^{\circ} 20^{\prime}$ & $290^{\circ} 0^{\prime}$ & $31^{\circ} 55^{\prime} \mathrm{N}$ & $36^{\circ} 0^{\prime} \mathrm{N}$ \\
\hline 25 & Śatabhiṣaja & $\lambda$ Aqr & $341^{\circ} 35^{\prime}$ & $320^{\circ} 0^{\prime}$ & $0^{\circ} 23^{\prime} \mathrm{S}$ & $0^{\circ} 30^{\prime} \mathrm{S}$ \\
\hline 26 & $\begin{array}{l}\text { Pūrva- } \\
\text { bhādrapada }\end{array}$ & $\alpha$ Peg & $353^{\circ} 29^{\prime}$ & $326^{\circ} 0^{\prime}$ & $19^{\circ} 24^{\prime} \mathrm{N}$ & $24^{\circ} 0^{\prime} \mathrm{N}$ \\
\hline $27 \mathrm{a}$ & $\begin{array}{l}\text { Uttara- } \\
\text { bhādrapad } \bar{a}^{\mathrm{c}}\end{array}$ & $\alpha$ And & $14^{\circ} 19^{\prime}$ & $337^{\circ} 0^{\prime}$ & $25^{\circ} 41^{\prime} \mathrm{N}$ & $26^{\circ} 0^{\prime} \mathrm{N}$ \\
\hline $27 \mathrm{~b}$ & $\begin{array}{l}\text { Uttara- } \\
\text { bhādrapad } \bar{a}\end{array}$ & $\gamma$ Peg & $9^{\circ} 09^{\prime}$ & $337^{\circ} 0^{\prime}$ & $12^{\circ} 36^{\prime} \mathrm{N}$ & $26^{\circ} 0^{\prime} \mathrm{N}$ \\
\hline 28 & Revatī & $\zeta$ Psc & $19^{\circ} 53^{\prime}$ & $359^{\circ} 50^{\prime}$ & $0^{\circ} 13^{\prime} \mathrm{S}$ & $0^{\circ} 0^{\prime}$ \\
\hline
\end{tabular}

a As identified by Burgess (1860)

b J2000.0 ecliptic cooridnates based on Stellarium software..

c For Uttara-bhādrapadā, longitude matches $\gamma$ Pegasi, while latitude matches $\alpha$ Andromeda. 


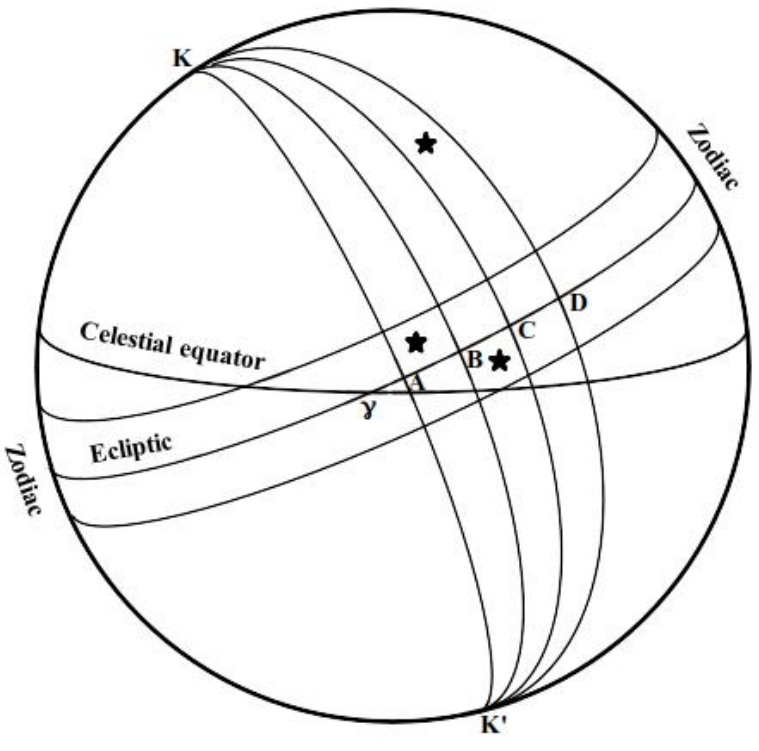

Figure 2 The division of celestial sphere in nakșatra zones

that during the time when Mahābhārata was written, it was still remembered that once upon a time Rohin̄ was the first nakșatra. As shown in Table 1, the list of nakșatra in Sūryasiddhānta begins with Aśvinī. A Jain astronomical text Sūryaprajňapti (10.1.32) gives five other systems besides the one followed by Jains, which started from Abhijīt and ended at Uttarāṣā five systems were: 1. Krttikā to Bharaṇī; 2. Maghā to Áśleșā; 3. Dhanișthā to Śravaṇa; 4. Aśvinī to Revatī; and 5. Bharaṇ̄ to Aśvinī.

According to Yajuṣ Vedāinga Jyotișa (verse 7), sun was at the first point of the Dhanișthā nakșatra on the day of winter solstice. This suggests that the system of Dhanișthā as the first nakșatra was in place when sun was observed at the beginning of Dhaniștha nakșatra on the day of winter solstice. Sun was in Maghā nakșatra on summer solstice around the same time when it was in Krttikā nakșatra on vernal equinox. Thus different systems of nakșatras were related to the careful observation of solstices and equinoxes. A story in Mahābhārata not only shows the importance of winter solstice but also the desire of the writers of Mahābhärata to carry forward this knowledge to future generations. The story is that of the death of one of the most beloved characters of Mahābhārata, Bhīṣma, and is told in Bhīṣma Parva (120.51-53). According to this story, when Bhissma is incapacitated on the battlefield, he refuses to die. He says that he will lie on the bed of arrows till the time of winter solstice. When sun starts his northward journey, only then he will leave this world. He waited for close to two months for winter solstice to take place and then left this world. This story has been passed on from generation to generation, and the dramatic nature of this narrative ensures that the listener will know the definition of winter solstice, which is the day when sun starts its northward journey. To make sure that the message gets passed on to future generations, a very dramatic situation was created in the storyline. From the details of the story, it is clear that the event cannot be historic as no one can control his time of death and lying on a bed of arrows for close to two months is an improbable event. What the story tells us is that winter solstice, and by implication summer solstice and equinoxes, were being carefully observed in India for many millennia. It would have been obvious to Indian astronomers that the position of sun among the stars during solstices and equinoxes was slowly changing due to the effect of precession. When the change in the position of sun became significant, the order of naksatras in the list was revised to reflect the new position of the sun on vernal equinox. Out of the different systems mentioned above, the nakșatra systems with orders Rohin̄ī to Krttikā, Krttikā to Bharaṇī, Bharaṇī to Aśvinī, and Aśvin̄̄ to Revatī are important for correct interpretation of coordinates of yogatārās given in Sūryasiddhānta. From Table 1, it is seen that the order of nakșatras is Aśvin̄̄, Bharaṇ̄, Krttikā, and Rohiṇ̄ according to Sūryasiddhānta. Thus first nakșatra in the list was sequentially changed from Rohin̄i to Krttikā, then from Krttikā to Bharaṇi, and finally from Bharaṇī to Aśvinī. As the original list of nakṣatras started with Rohin̄i, it is reasonable to assume that the yogatārā of Rohiṇ̄ was at zero longitude of the original nakșatra system. The Rohiṇi system with yogatārā of Rohin̄ī, Aldebaran, at zero longitude is shown in Figure 3. The part of celestial sphere close to ecliptic is shown, where nakșatra boundaries have been approximated to straight lines for illustrative purpose. Actual construction of nakșatra boundaries should be done according to the principle illustrated in Figure 2.

The ecliptic longitudes of yogatārās, as identified by Burgess (1860), in Rohiṇ̄ system are shown in Table 3 along with the longitudes (dhruvaka) of yogatārās given 


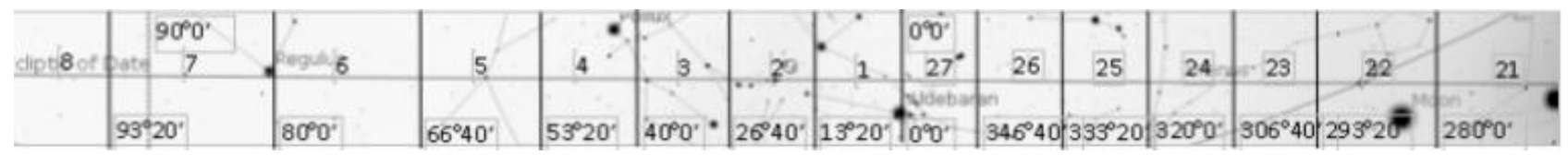

(a) Rohiṇī system

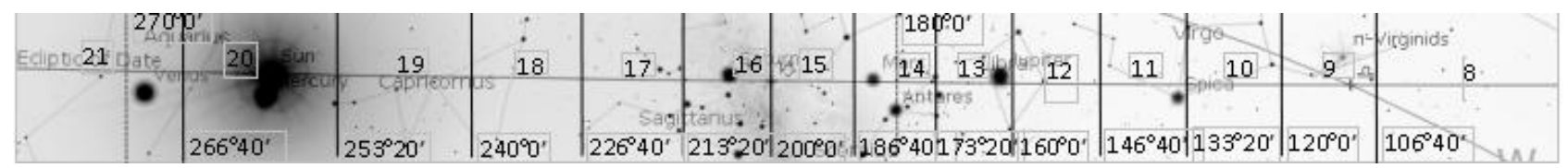

(b) Rohiṇī system (continued)

Figure 3

in Sūryasiddhānta (8.1-9). The numbers in Figure 3 refer to the serial number of nakșatras shown in Table 3. The ecliptic longitudes in Rohiṇ̄ system were obtained by setting a date on which the ecliptic longitude of the yogatārā of Rohin̄i, Aldebaran, became $0^{\circ} 0^{\prime}$. This date was found to be June $12,-3044$ by trial and error using Stellarium software. From Table 3, it is seen that the longitude of the yogatārā of Rohin̄ī had shifted by approximately $50^{\circ}$ according to Sūryasiddhānta from its zero point in Rohiṇī system. As shown in Figure 3a, nakșatra boundaries are at $13^{\circ} 20^{\prime}, 26^{\circ} 40^{\prime}, 40^{\circ} 0^{\prime}, 53^{\circ} 20^{\prime}$, and so on. If the ecliptic longitudes were updated by shifting the zero point of longitude to the beginning of Revati nakșatra, which is fourth nakṣatra from Rohini, then $53^{\circ} 20^{\prime}$ should have been added to the ecliptic longitude in Rohin̄i system instead of $50^{\circ}$. This raises the possibility that another system was also in use, and there was confusion between these two systems resulting in a mix of data derived from two different systems. From Table 3, it is seen that the difference between ecliptic longitudes of the yogatārās of Rohin̄i and Krttikā is approximately $10^{\circ}$ or three quarters of a nakșatra. A nakșatra system with its origin at the yogatārā of Krttikā will have nakșatra boundaries at one quarter of a nakșatra or $3^{\circ} 20^{\prime}$ from the nakșatra boundaries in the Rohin̄i system. While Sūryasiddhānta gives $180^{\circ}$ as the longitude of Citrā (see Table 1), Paitāmahasiddhānta gives $183^{\circ}$ (Pingree and Morrissey, 1989). This could simply be a result of using coordinate systems having boundaries $3^{\circ} 20^{\prime}$ apart. The Krttikā system with yogatārā of Krttikāa, Alcyone, at zero longitude is shown in Figure 4. The part of celestial sphere close to ecliptic is shown, where nakșatra boundaries have been approximated to straight lines for illustrative purpose. As mentioned earlier, actual construction of nakșatra boundaries should be done according to the principle illustrated in Figure 2.

The ecliptic longitudes of yogatārās, as identified by Burgess (1860), in Krttikā system are shown in Table 4 along with the longitudes (dhruvaka) of yogatārās given in Sūryasiddhānta (8.1-9). The numbers in Figure 4 refer to the serial number of naksatras shown in Table 4. The ecliptic longitudes in Krttikā system were obtained by setting a date on which the ecliptic longitude of the yogatārā of Krttikā, Alcyone, became $0^{\circ} 0^{\prime}$. This date was found to be April 17, -2336 by trial and error using Stellarium software. From Table 4, it is seen that the longitude of the yogatārā of Krttikā had shifted by $37^{\circ} 30^{\prime}$ according to Sūryasiddhānta from its zero point in Krttikā system.

Some observations can be made regarding the nakșatra boundaries in Rohin̄i and Krttikā systems. According to Sūryasiddhānta, yogatārā of Revatī ( $\zeta$ Piscium) is near the origin of the coordinate system. However, $\zeta$ Piscium is a very dim star with an apparent magnitude of 5.20. Why would such a star be chosen at the origin? Pingree and Morrissey (1989) write:

It is disturbing that $\zeta$ Piscium is so dim, and that its $\alpha$ is 0 ; 7h or nearly $2^{\circ}$ too high on the assumption that the original list was drawn up in $\mathrm{AD} 425$, though the situation, of course, improves as one increases that date. But there are no other visible stars in the neighbourhood.

The yogatārā of Revatī was not at the origin of the coordinate system, when it was designed. The yogatārā of Rohin̄i , Aldebaran, was at the origin of the coordinate system, which is a bright star with apparent magnitude of 
Table 3 Longitudes of yogatārās in Rohiṇ̄ system.

\begin{tabular}{|c|c|c|c|c|}
\hline No. & Nakṣatra & $\begin{array}{c}\text { Junction-star } \\
(\text { yogatārā })^{\mathbf{a}}\end{array}$ & $\begin{array}{c}\text { Ecliptic } \\
\text { longitude }^{b}\end{array}$ & $\begin{array}{l}\text { Dhruvaka } \\
\text { (longitude) }^{c}\end{array}$ \\
\hline 1 & Rohiṇ̄ & $\alpha \mathrm{Tau}$ & $0^{\circ} 00^{\prime}$ & $49^{\circ} 30^{\prime}$ \\
\hline 2 & Mrgaśirā & $\delta$ Ori & $13^{\circ} 58^{\prime}$ & $63^{\circ} 0^{\prime}$ \\
\hline 3 & $\bar{A} r d r a \bar{a}$ & $\alpha$ Ori & $18^{\circ} 58^{\prime}$ & $67^{\circ} 20^{\prime}$ \\
\hline 4 & Punarvasu & $\beta$ Gem & $44^{\circ} 20^{\prime}$ & $93^{\circ} 0^{\prime}$ \\
\hline 5 & Puṣya & $\delta \mathrm{Cnc}$ & $58^{\circ} 56^{\prime}$ & $106^{\circ} 0^{\prime}$ \\
\hline 6 & Áśleșā & $\epsilon$ Hya & $63^{\circ} 02^{\prime}$ & $109^{\circ} 0^{\prime}$ \\
\hline 7 & Maghā & $\alpha$ Leo & $80^{\circ} 29^{\prime}$ & $129^{\circ} 0^{\prime}$ \\
\hline 8 & $\begin{array}{l}\text { Pūrva- } \\
\text { phālgunī }\end{array}$ & $\delta$ Leo & $91^{\circ} 11^{\prime}$ & $144^{\circ} 0^{\prime}$ \\
\hline 9 & $\begin{array}{l}\text { Uttara- } \\
\text { phālgunī }\end{array}$ & $\beta$ Leo & $102^{\circ} 20^{\prime}$ & $155^{\circ} 0^{\prime}$ \\
\hline 10 & Hasta & $\delta \mathrm{Crv}$ & $124^{\circ} 04^{\prime}$ & $170^{\circ} 0^{\prime}$ \\
\hline 11 & Citrā & $\alpha$ Vir & $134^{\circ} 11^{\prime}$ & $180^{\circ} 0^{\prime}$ \\
\hline 12 & Swāti & $\alpha$ Boo & $134^{\circ} 10^{\prime}$ & $199^{\circ} 0^{\prime}$ \\
\hline 13 & Viśākhā & $\iota \mathrm{Lib}$ & $161^{\circ} 20^{\prime}$ & $213^{\circ} 0^{\prime}$ \\
\hline 14 & Anurādhā & $\delta$ Sco & $172^{\circ} 52^{\prime}$ & $224^{\circ} 0^{\prime}$ \\
\hline 15 & Jyeșthā & $\alpha$ Sco & $180^{\circ} 05^{\prime}$ & $229^{\circ} 0^{\prime}$ \\
\hline 16 & Mūla & $\in \mathrm{Sco}$ & $194^{\circ} 54^{\prime}$ & $241^{\circ} 0^{\prime}$ \\
\hline 17 & Pūrvāṣā & $\delta$ Sgr & $204^{\circ} 50^{\prime}$ & $254^{\circ} 0^{\prime}$ \\
\hline 18 & Uttarāṣāạhhā & $\sigma \mathrm{Sgr}$ & $212^{\circ} 40^{\prime}$ & $260^{\circ} 0^{\prime}$ \\
\hline & Abhijīt & $\alpha \operatorname{Lyr}$ & $215^{\circ} 22^{\prime}$ & $266^{\circ} 40^{\prime}$ \\
\hline 19 & Śravaṇa & $\alpha \mathrm{Aql}$ & $231^{\circ} 14^{\prime}$ & $280^{\circ} 0^{\prime}$ \\
\hline 20 & Dhanișthā & $\beta$ Del & $246^{\circ} 44^{\prime}$ & $290^{\circ} 0^{\prime}$ \\
\hline 21 & Śatabhișaja & $\lambda$ Aqr & $271^{\circ} 49^{\prime}$ & $320^{\circ} 0^{\prime}$ \\
\hline 22 & $\begin{array}{l}\text { Pūrva- } \\
\text { bhādrapadā }\end{array}$ & $\alpha$ Peg & $283^{\circ} 57^{\prime}$ & $326^{\circ} 0^{\prime}$ \\
\hline 23 & $\begin{array}{l}\text { Uttara- } \\
\text { bhādrapadā }\end{array}$ & $\alpha$ And & $304^{\circ} 51^{\prime}$ & $337^{\circ} 0^{\prime}$ \\
\hline $24 \mathrm{a}$ & $\begin{array}{l}\text { Uttara- } \\
\text { bhādrapadā }\end{array}$ & $\gamma \mathrm{Peg}$ & $299^{\circ} 36^{\prime}$ & $337^{\circ} 0^{\prime}$ \\
\hline $24 \mathrm{~b}$ & Revatī & $\zeta$ Psc & $310^{\circ} 01^{\prime}$ & $359^{\circ} 50^{\prime}$ \\
\hline 25 & Aśvin̄̄ & $\beta$ Ari & $324^{\circ} 15^{\prime}$ & $8^{\circ} 0^{\prime}$ \\
\hline 26 & Bharaṇī & 35 Ari & $337^{\circ} 19^{\prime}$ & $20^{\circ} 0^{\prime}$ \\
\hline 27 & Krttikā & $\eta \mathrm{Tau}$ & $350^{\circ} 18^{\prime}$ & $37^{\circ} 30^{\prime}$ \\
\hline
\end{tabular}

a As identified by Burgess (1860).

b Ecliptic longitudes on June 12, -3044 based on Stellarium software.

c Longitudes as given in Süryasiddhānta 8.1-9. 


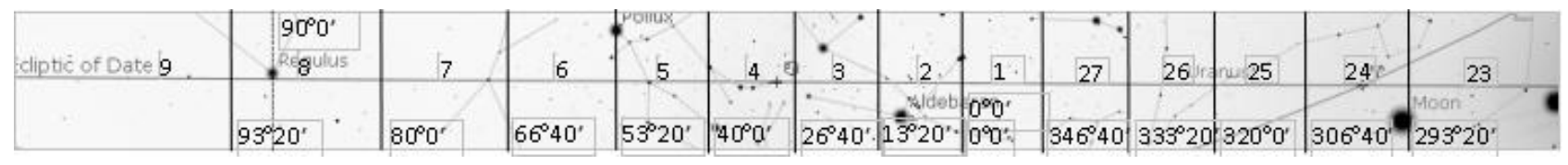

(a) Kṛttikā system.

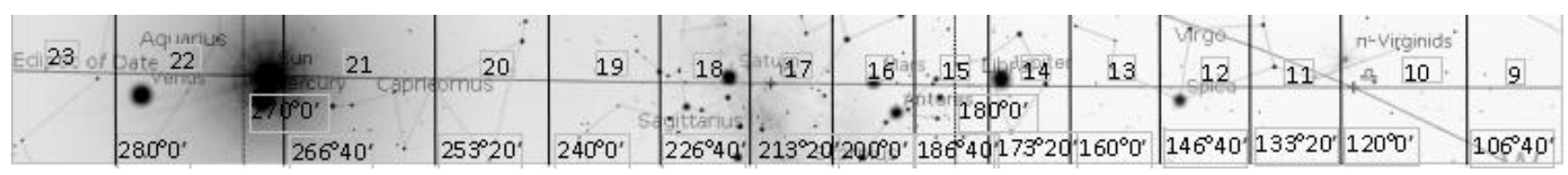

(b) Kṛttikā system (continued).

Figure 4

0.85. The yogatārā of Revatī was not even a boundary star in the original system. It became a boundary star in the Krttikā system devised later. The yogatārā of Punarvasu, Pollux, also became a boundary star in the Krttikā system (see Figure 4a).

The yogatārā of Jyeșthā, Antares, is at $180^{\circ}$ in the Rohiṇi system (see Figure 3b and Table 3). When vernal equinox was at the yogatārā of Rohin̄i, then autumnal equinox was at the yogatārā of Jyeșthā. The yogatārā of Maghā, Regulus, is a boundary star in the Rohiṇ̄ system (see Figure 3a). Its longitude is close to $80^{\circ}$ in the Rohiṇi system as shown in Table 3. Its longitude is $90^{\circ}$ in the Krttik $\bar{a}$ system as shown in Table 4. Thus when vernal equinox fell on the yogatārā of Krttikā, the summer solstice fell on the yogatārā of Maghā. With the precise determination of nakșatra boundaries, coordinates given in astronomical texts can be better analyzed to check whether some of the yogatārās have been misidentified.

\section{Reassessing the identifications of yogatārās}

It is clear that Indian astronomers did not keep measuring the coordinates because they believed the coordinates to be ecliptic coordinates which do not change when fixed to stars in a sidereal system. The coordinates of the yogatārā of $A s ́ v i n \bar{\imath}$ is given as $8^{\circ}$ longitude and $10^{\circ}$ latitude in Sūryasiddhānta, Paitāmahasiddhānta, Mahābhāskarīya and Laghubhāskarīya, and by Brahmagupta, Vateśvara, Lalla, and Gạ̣eśa (Pingree and Morrissey, 1989). It was never changed as would be expected in a sidereal ecliptic coordinate system. The reason the data given in texts do not fit to a single time period is due to a mix up of data during the last update when reference point was changed to account for precession as well as due to misidentification of some yogatārās. Based on the analysis of longitude data, following six yogatārās have been misidentified.

\subsection{The yogatārā of Aśvinī}

Since Aśvinī is the first nakșatra in the list of nakșatras given in Süryasiddhānta and other texts of classical period, it is of vital importance to correctly identify the yogatārā of Aśvinī. As mentioned above, every text gives the coordinates of the yogatārā of Aśvinī as $8^{\circ}$ longitude and $10^{\circ}$ latitude. Currently accepted yogatārā of $A s ́ v i n \bar{\imath}$ is Sheratan ( $\beta$ Ari) with apparent magnitude of 2.60 and $\mathrm{J} 2000.0$ ecliptic longitude and latitude of $33^{\circ} 58^{\prime}$ and $8^{\circ} 29^{\prime}$ respectively. The star Hamal ( $\alpha$ Ari) is the brightest star of the Aries constellation. Hamal ( $\alpha$ Ari) has apparent magnitude of 2.00 and J2000.0 ecliptic longitude and latitude of $37^{\circ} 40^{\prime}$ and $9^{\circ} 58^{\prime}$ respectively. The ecliptic latitude of $9^{\circ} 58^{\prime}$ of Hamal matches closely with the latitude of $10^{\circ}$ given in Sūryasiddhānta. This raises the possibility that the yogatārā of Aśvinī is Hamal instead of Sheratan. This is confirmed from the longitude of $8^{\circ}$ given in every text. The ecliptic longitude of Hamal is $327^{\circ} 50^{\prime}$ in Rohin̄ $\bar{l}$ system. That is when the ecliptic longitude of Rohiṇi was $0^{\circ} 0^{\prime}$ on June $12,-3044$, the ecliptic longitude of Hamal

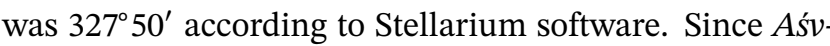

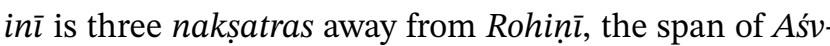
in̄ nakșatra in Rohin̄i system is $320^{\circ} 0^{\prime}$ to $333^{\circ} 20^{\prime}$. This means that Hamal is $7^{\circ} 50^{\prime}$ away from the beginning of $A s^{\prime} \mathrm{v}$ inī nakṣatra in Rohiṇī system and when nakṣatra list was updated to begin with Aśvinī, Hamal would have eclip- 
Table 4 Longitudes of yogatārās in Krttikā system.

\begin{tabular}{|c|c|c|c|c|}
\hline No. & Nakșatra & $\begin{array}{l}\text { Junction-star } \\
(\text { yogatārāa) }\end{array}$ & $\begin{array}{c}\text { Ecliptic } \\
\text { longitude }^{b}\end{array}$ & $\begin{array}{l}\text { Dhruvaka } \\
\text { (longitude) }^{c}\end{array}$ \\
\hline 1 & Krttikā & $\eta$ Tau & $0^{\circ} 00^{\prime}$ & $37^{\circ} 30^{\prime}$ \\
\hline 2 & Rohiṇ̄ & $\alpha \mathrm{Tau}$ & $9^{\circ} 43^{\prime}$ & $49^{\circ} 30^{\prime}$ \\
\hline 3 & Mrgaśirā & $\lambda$ Ori & $23^{\circ} 40^{\prime}$ & $63^{\circ} 0^{\prime}$ \\
\hline 4 & $\bar{A} r d r \bar{a}$ & $\alpha$ Ori & $28^{\circ} 41^{\prime}$ & $67^{\circ} 20^{\prime}$ \\
\hline 5 & Punarvasu & $\beta \mathrm{Gem}$ & $53^{\circ} 55^{\prime}$ & $93^{\circ} 0^{\prime}$ \\
\hline 6 & Pușya & $\delta \mathrm{Cnc}$ & $68^{\circ} 39^{\prime}$ & $106^{\circ} 0^{\prime}$ \\
\hline 7 & Áśleșā & $\epsilon$ Hya & $72^{\circ} 41^{\prime}$ & $109^{\circ} 0^{\prime}$ \\
\hline 8 & Maghā & $\alpha$ Leo & $90^{\circ} 08^{\prime}$ & $129^{\circ} 0^{\prime}$ \\
\hline 9 & Pūrva-phālgunī & $\delta$ Leo & $100^{\circ} 56^{\prime}$ & $144^{\circ} 0^{\prime}$ \\
\hline 10 & Uttara-phālgunī & $\beta$ Leo & $111^{\circ} 59^{\prime}$ & $155^{\circ} 0^{\prime}$ \\
\hline 11 & Hasta & $\delta \mathrm{Crv}$ & $133^{\circ} 43^{\prime}$ & $170^{\circ} 0^{\prime}$ \\
\hline 12 & Citrā & $\alpha \operatorname{Vir}$ & $143^{\circ} 53^{\prime}$ & $180^{\circ} 0^{\prime}$ \\
\hline 13 & Swāti & $\alpha$ Boo & $143^{\circ} 56^{\prime}$ & $199^{\circ} 0^{\prime}$ \\
\hline 14 & Viśākhā & $\iota \mathrm{Lib}$ & $171^{\circ} 02^{\prime}$ & $213^{\circ} 0^{\prime}$ \\
\hline 15 & Anurādhā & $\delta$ Sco & $182^{\circ} 34^{\prime}$ & $224^{\circ} 0^{\prime}$ \\
\hline 16 & Jyeșthā & $\alpha \operatorname{Sco}$ & $189^{\circ} 47^{\prime}$ & $229^{\circ} 0^{\prime}$ \\
\hline 17 & Mūla & $\epsilon \mathrm{Sco}$ & $204^{\circ} 36^{\prime}$ & $241^{\circ} 0^{\prime}$ \\
\hline 18 & Pūrvāṣā & $\delta \mathrm{Sgr}$ & $214^{\circ} 32^{\prime}$ & $254^{\circ} 0^{\prime}$ \\
\hline \multirow[t]{2}{*}{19} & Uttarāṣāạhhā & $\sigma \mathrm{Sgr}$ & $222^{\circ} 22^{\prime}$ & $260^{\circ} 0^{\prime}$ \\
\hline & Abhijīt & $\alpha \operatorname{Lyr}$ & $225^{\circ} 08^{\prime}$ & $266^{\circ} 40^{\prime}$ \\
\hline 20 & Śravaṇa & $\alpha \mathrm{Aql}$ & $241^{\circ} 03^{\prime}$ & $280^{\circ} 0^{\prime}$ \\
\hline 21 & Dhanișthā & $\beta$ Del & $256^{\circ} 26^{\prime}$ & $290^{\circ} 0^{\prime}$ \\
\hline 22 & Śatabhișaja & $\lambda$ Aqr & $281^{\circ} 32^{\prime}$ & $320^{\circ} 0^{\prime}$ \\
\hline 23 & $\begin{array}{l}\text { Pūrva- } \\
\text { bhādrapadā }\end{array}$ & $\alpha$ Peg & $293^{\circ} 37^{\prime}$ & $326^{\circ} 0^{\prime}$ \\
\hline $24 \mathrm{a}$ & $\begin{array}{l}\text { Uttara- } \\
\text { bhādrapadā }\end{array}$ & $\alpha$ And & $314^{\circ} 31^{\prime}$ & $337^{\circ} 0^{\prime}$ \\
\hline $24 b$ & $\begin{array}{l}\text { Uttara- } \\
\text { bhādrapadā }\end{array}$ & $\gamma$ Peg & $309^{\circ} 17^{\prime}$ & $337^{\circ} 0^{\prime}$ \\
\hline 25 & Revatī & $\zeta$ Psc & $319^{\circ} 44^{\prime}$ & $359^{\circ} 50^{\prime}$ \\
\hline 26 & Aśvin̄̄ & $\beta$ Ari & $333^{\circ} 57^{\prime}$ & $8^{\circ} 0^{\prime}$ \\
\hline 27 & Bharaṇ̄ & 35 Ari & $347^{\circ} 00^{\prime}$ & $20^{\circ} 0^{\prime}$ \\
\hline
\end{tabular}

a As identified by Burgess (1860)

b Ecliptic longitudes on April 17, -2336 based on Stellarium software

c Longitudes as given in Süryasiddhānta 8.1-9. 
tic longitude of $7^{\circ} 50^{\prime}$ in the new system. This is a close match with $8^{\circ}$ longitude of the yogatārā of Aśvinī given in all astronomical texts. Thus Hamal has excellent match

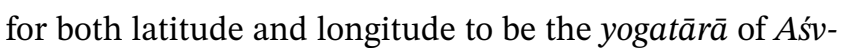
inī.

The identification of Hamal as the yogatārā of Aśvini with $8^{\circ}$ longitude from the beginning of $A$ śvinī provides a zero point from which the longitudes of some of the yogatārā have been measured. The date on which the ecliptic longitude of Hamal was $8^{\circ} 0^{\prime}$ is found to be April 13, -130 by trial and error using Stellarium software. Table 5 shows the ecliptic longitude of yogatārās when Hamal had an ecliptic longitude of $8^{\circ} 0^{\prime}$. This system has been named $A s ́ v i n \bar{l}$-beginning Rohiṇ̄ system as it measures the longitude from the boundary of $A s ́ v i n \bar{l}$ in Rohiṇ̄ system.

Table 5 also shows the ecliptic longitude of yogatārās when the yogatārā of Revatī ( $\zeta$ Piscium) had an ecliptic longitude of $359^{\circ} 50^{\prime}$. This system has been named $A s ́ v$ in̄i-beginning Krttikā system as it measures the longitude from the boundary of Aśvinī nakșatra in Krttikā system. According to Table 4, the ecliptic longitude of the yogatārā of Revatī ( $\zeta$ Piscium) is $319^{\circ} 44^{\prime}$ in Krttikā system, which means the yogatārā of Revatī is a boundary star in Krttikā system as the naksatra boundary between Revatī and Aśvin $\bar{\imath}$ is at $320^{\circ}$. Since the boundary of Revatī is $40^{\circ}$ from the boundary of Krttikā, the coordinate of the yogatārā of Revatī is $359^{\circ} 44^{\prime}$ in Aśvinī-beginning Krttikā system, which is an excellent match with the value of $359^{\circ} 50^{\prime}$ given in Sūryasiddhānta. The date on which the ecliptic longitude of Revatī star ( $\zeta$ Piscium) was $359^{\circ} 50^{\prime}$ is found to be December 12, 563 by trial and error using Stellarium software. It should be noted that vernal equinox moves in the opposite direction of the order of nakșatras. Since vernal equinox was at the boundary of Aśvinī and Revatī in 130 BCE in Aśvin̄̄-beginning Rohiṇ̄ system, it implies that vernal equinox was in Aśvinī nakșatra for approximately 960 years prior to c. 130 BCE. So the order of nakșatra could have been updated to begin with Aśvinī at any time between c. 1090 BCE and c. 130 BCE. Similarly, the coordinates of the yogatārā of Revatī, $\zeta$ Piscium, could have been updated to $359^{\circ} 50^{\prime}$ at any time period between c. $400 \mathrm{BCE}$ and c. $560 \mathrm{CE}$. Since the longitude of many yogatārās given in Süryasiddhānta match the respective longitudes in Aśvinī-beginning Krttikā system, it stands to reason that an attempt was made to update the coordinates between c. $400 \mathrm{BCE}$ and c. $560 \mathrm{CE}$. The updating of coordinates in two different systems created a confusion resulting in a list that has some coordinates from $A s ́ v i n \bar{l}-$ beginning Rohiṇ̄ system, some coordinates from Aśvin̄̄beginning Krttikā system, and some coordinates resulting from confusion between Rohiṇ̄ and Krttikā systems.

To illustrate this point, another column with title "Aśvinī-beginning Krttikā offset" has been added in Table 5 . The values in this column are $3^{\circ} 20^{\prime}$ (one quarter of the span of a nakșatra) lesser than the values in Aśvinibeginning Krttikā system. It should be noted that the nakșatra boundaries in Rohin̄i and Krttika systems are separated by one quarter of the span of a naksatra. Confusion between these two systems would have resulted in subtracting $3^{\circ} 20^{\prime}$ from the values in Aśvinī-beginning Krttika system. Another reason for error in longitudes would have been an attempt to keep the yogatārās within their boundaries. Since the difference in longitude between Aśvin̄̄-beginning Rohiṇ̄ and Aśvin̄̄-beginning Kṛttika systems is $10^{\circ}$, the longitude of Hamal would be $18^{\circ}$ in $A$ śvinī-beginning Krttikā system, but this would put Hamal outside the boundary of Aśvinī, as each nakșatra has span of $13^{\circ} 20^{\prime}$. So the longitude of Hamal in $A s^{\prime} v$ in̄̄-beginning Rohiṇ̄ system was kept in Aśvin̄̄-beginning Krttikā system.

\subsection{The yogatārā of Bharaṇi}

Currently accepted yogatārā of Bharaṇi is Barani II (35 Ari) with apparent magnitude of 4.65 and J2000.0 ecliptic longitude and latitude of $46^{\circ} 56^{\prime}$ and $11^{\circ} 19^{\prime}$ respectively. However, nearby star Bharaṇi (41 Ari) is brighter than Barani II and should be the yogatārā of Bharaṇi. As seen in Table 5, the longitude of Barani II (35 Ari) in Aśvinī-beginning Rohin̄i system is $17^{\circ} 22^{\prime}$, while the longitude given in Süryasiddhānta is $20^{\circ}$. The longitude of Bharaṇ̄ (41 Ari) in Aśvin̄̄-beginning Rohiṇ̄ system is $18^{\circ} 36^{\prime}$, which is a better match with the longitude given in Sūryasiddhānta. Bharaṇ̄ (41 Ari) has latitude of $10^{\circ} 27^{\prime}$, which is a reasonable match with $12^{\circ}$ latitude given in Sūryasiddhānta. Bharaṇī (41 Ari) is better suited to be the yogatārā of Bharaṇi due to it being brighter and matching longitude better.

\subsection{The yogatārā of Hasta}

The accepted yogatārā of Hasta is Algorab ( $\delta$ Crv) with apparent magnitude of 2.90 and J2000.0 ecliptic longi- 
Table 5 Ecliptic lognitude of yogatārās in Aśvinī-beginning Rohị̣̄ and Aśvinī-beginning Krttikā systems.

\begin{tabular}{|c|c|c|c|c|c|c|}
\hline & & & $\begin{array}{c}\text { Aśvinī } \\
\text { beginning } \\
\text { Rohiṇī system } \\
\text { (Apr 13, -130) }\end{array}$ & $\begin{array}{c}\text { Aśvinī } \\
\text { beginning } \\
\text { Krttikā system } \\
(\text { Dec 12, 563) }\end{array}$ & $\begin{array}{c}\text { Aśvinī } \\
\text { beginning } \\
\text { Krttikā offset }\end{array}$ & Sūryasiddhānta \\
\hline No. & Nakṣatra & $\begin{array}{c}\text { Junction-star } \\
(\text { yogatārā })^{\mathrm{a}}\end{array}$ & $\begin{array}{c}\text { Relative } \\
\text { longitude }\end{array}$ & $\begin{array}{c}\text { Relative } \\
\text { longitude }\end{array}$ & $\begin{array}{c}\text { Relative } \\
\text { longitude }\end{array}$ & $\begin{array}{c}\text { Dhruvaka } \\
\text { (longitude) }\end{array}$ \\
\hline 1 & Aśvin̄̄ & $\beta$ Ari & $4^{\circ} 21^{\prime}$ & $13^{\circ} 58^{\prime}$ & $10^{\circ} 38^{\prime}$ & $8^{\circ} 0^{\prime}$ \\
\hline 2 & Bharaṇī & 35 Ari & $17^{\circ} 22^{\prime}$ & $26^{\circ} 58^{\prime}$ & $23^{\circ} 38^{\prime}$ & $20^{\circ} 0^{\prime}$ \\
\hline 3 & Krttikā & $\eta$ Tau & $30^{\circ} 23^{\prime}$ & $40^{\circ} 00^{\prime}$ & $36^{\circ} 40^{\prime}$ & $37^{\circ} 30^{\prime}$ \\
\hline 4 & Rohiṇ̄̄ & $\alpha$ Tau & $40^{\circ} 09^{\prime}$ & $49^{\circ} 46^{\prime}$ & $46^{\circ} 26^{\prime}$ & $49^{\circ} 30^{\prime}$ \\
\hline 5 & Mrgaśirā & $\lambda$ Ori & $54^{\circ} 05^{\prime}$ & $63^{\circ} 42^{\prime}$ & $60^{\circ} 22^{\prime}$ & $63^{\circ} 0^{\prime}$ \\
\hline 6 & $\bar{A} r d r a \bar{a}$ & $\alpha$ Ori & $59^{\circ} 07^{\prime}$ & $68^{\circ} 45^{\prime}$ & $65^{\circ} 25^{\prime}$ & $67^{\circ} 20^{\prime}$ \\
\hline 7 & Punarvasu & $\beta \mathrm{Gem}$ & $83^{\circ} 57^{\prime}$ & $93^{\circ} 27^{\prime}$ & $90^{\circ} 07^{\prime}$ & $93^{\circ} 0^{\prime}$ \\
\hline 8 & Pușya & $\delta \mathrm{Cnc}$ & $99^{\circ} 05^{\prime}$ & $108^{\circ} 42^{\prime}$ & $105^{\circ} 22^{\prime}$ & $106^{\circ} 0^{\prime}$ \\
\hline 9 & Āśleșāu & $\epsilon$ Hya & $102^{\circ} 55^{\prime}$ & $112^{\circ} 28^{\prime}$ & $109^{\circ} 08^{\prime}$ & $109^{\circ} 0^{\prime}$ \\
\hline 10 & Maghā & $\alpha$ Leo & $120^{\circ} 22^{\prime}$ & $129^{\circ} 56^{\prime}$ & $126^{\circ} 36^{\prime}$ & $129^{\circ} 0^{\prime}$ \\
\hline 11 & $\begin{array}{l}\text { Pūrva- } \\
\text { phālgunī }\end{array}$ & $\delta$ Leo & $131^{\circ} 31^{\prime}$ & $141^{\circ} 12^{\prime}$ & $137^{\circ} 52^{\prime}$ & $144^{\circ} 0^{\prime}$ \\
\hline 12 & $\begin{array}{l}\text { Uttara- } \\
\text { phālgunī }\end{array}$ & $\beta$ Leo & $142^{\circ} 11^{\prime}$ & $151^{\circ} 45^{\prime}$ & $148^{\circ} 25^{\prime}$ & $155^{\circ} 0^{\prime}$ \\
\hline 13 & Hasta & $\delta \mathrm{Crv}$ & $163^{\circ} 59^{\prime}$ & $173^{\circ} 33^{\prime}$ & $170^{\circ} 13^{\prime}$ & $170^{\circ} 0^{\prime}$ \\
\hline 14 & Citrā & $\alpha \operatorname{Vir}$ & $174^{\circ} 15^{\prime}$ & $183^{\circ} 52^{\prime}$ & $180^{\circ} 32^{\prime}$ & $180^{\circ} 0^{\prime}$ \\
\hline 15 & Swāti & $\alpha$ Boo & $174^{\circ} 30^{\prime}$ & $184^{\circ} 09^{\prime}$ & $180^{\circ} 49^{\prime}$ & $199^{\circ} 0^{\prime}$ \\
\hline 16 & Viśākhā & $\iota \mathrm{Lib}$ & $201^{\circ} 25^{\prime}$ & $211^{\circ} 01^{\prime}$ & $207^{\circ} 41^{\prime}$ & $213^{\circ} 0^{\prime}$ \\
\hline 17 & Anurādhā & $\delta \mathrm{Sco}$ & $212^{\circ} 58^{\prime}$ & $222^{\circ} 35^{\prime}$ & $219^{\circ} 15^{\prime}$ & $224^{\circ} 0^{\prime}$ \\
\hline 18 & Jyeștha $\bar{a}$ & $\delta \mathrm{Sco}$ & $220^{\circ} 10^{\prime}$ & $229^{\circ} 46^{\prime}$ & $226^{\circ} 26^{\prime}$ & $229^{\circ} 0^{\prime}$ \\
\hline 19 & Mūla & $\lambda \mathrm{Sco}$ & $234^{\circ} 59^{\prime}$ & $244^{\circ} 35^{\prime}$ & $241^{\circ} 15^{\prime}$ & $241^{\circ} 0^{\prime}$ \\
\hline 20 & Pūrvāṣā & $\delta \mathrm{Sgr}$ & $244^{\circ} 57^{\prime}$ & $254^{\circ} 34^{\prime}$ & $251^{\circ} 14^{\prime}$ & $254^{\circ} 0^{\prime}$ \\
\hline 21 & Uttarāṣā & $\sigma \mathrm{Sgr}$ & $252^{\circ} 46^{\prime}$ & $262^{\circ} 23^{\prime}$ & $259^{\circ} 03^{\prime}$ & $260^{\circ} 0^{\prime}$ \\
\hline 22 & Abhijīt & $\alpha \operatorname{Lyr}$ & $255^{\circ} 40^{\prime}$ & $265^{\circ} 18^{\prime}$ & $261^{\circ} 58^{\prime}$ & $266^{\circ} 40^{\prime}$ \\
\hline 23 & Śravaṇa & $\alpha \mathrm{Aql}$ & $271^{\circ} 50^{\prime}$ & $281^{\circ} 33^{\prime}$ & $278^{\circ} 13^{\prime}$ & $280^{\circ} 0^{\prime}$ \\
\hline 24 & Dhanișțhā & $\beta$ Del & $286^{\circ} 47^{\prime}$ & $296^{\circ} 23^{\prime}$ & $293^{\circ} 03^{\prime}$ & $290^{\circ} 0^{\prime}$ \\
\hline 25 & Śatabhiṣaja & $\lambda$ Aqr & $311^{\circ} 57^{\prime}$ & $321^{\circ} 34^{\prime}$ & $318^{\circ} 14^{\prime}$ & $320^{\circ} 0^{\prime}$ \\
\hline 26 & $\begin{array}{l}\text { Pūrva- } \\
\text { bhādrapadā }\end{array}$ & $\alpha$ Peg & $323^{\circ} 57^{\prime}$ & $333^{\circ} 32^{\prime}$ & $330^{\circ} 12^{\prime}$ & $326^{\circ} 0^{\prime}$ \\
\hline $27 \mathrm{a}$ & $\begin{array}{l}\text { Uttara- } \\
\text { bhādrapadā }\end{array}$ & $\alpha$ And & $344^{\circ} 48^{\prime}$ & $354^{\circ} 22^{\prime}$ & $351^{\circ} 02^{\prime}$ & $337^{\circ} 0^{\prime}$ \\
\hline $27 \mathrm{~b}$ & $\begin{array}{l}\text { Uttara- } \\
\text { bhādrapadā }\end{array}$ & $\gamma$ Peg & $339^{\circ} 36^{\prime}$ & $349^{\circ} 12^{\prime}$ & $345^{\circ} 52^{\prime}$ & $337^{\circ} 0^{\prime}$ \\
\hline 28 & Revatī & $\zeta$ Psc & $350^{\circ} 12^{\prime}$ & $359^{\circ} 50^{\prime}$ & $356^{\circ} 30^{\prime}$ & $359^{\circ} 50^{\prime}$ \\
\hline
\end{tabular}

${ }^{\text {a }}$ As identified by Burgess (1860). 
tude and latitude of $193^{\circ} 27^{\prime}$ and $-12^{\circ} 12^{\prime}$ respectively. As seen in Table 5, the longitude given in Süryasiddhānta is $170^{\circ} 0^{\prime}$, which is $3^{\circ} 33^{\prime}$ lesser than the relative longitude of $173^{\circ} 33^{\prime}$ in $A s ́ v i n \bar{l}$-beginning Krttikā system. Nearby star Gienah ( $\gamma$ Crv) has apparent magnitude of 2.55 and J2000.0 ecliptic longitude and latitude of $190^{\circ} 44^{\prime}$ and $-14^{\circ} 30$ respectively. The relative longitude of Gienah is $170^{\circ} 50^{\prime}$ in Aśvinī-beginning Krttika system, which is a good match with the relative longitude of $170^{\circ} 0^{\prime}$ given in Sūryasiddhānta. Though the latitude of Algorab is a better match for $-11^{\circ} 0^{\prime}$ latitude given in Süryasiddhānta compared to Gienah, on account of brightness and better match of longitude, Gienah has a better claim to be the yogatārā of Hasta nakșatra.

\subsection{The yogatārā of Swāti}

The currently accepted yogatārā of $S w a \overline{t i}$ is Arcturus ( $\alpha$ Boo), which is a very bright star with apparent magnitude of 0.15 and J2000.0 ecliptic longitude and latitude of $204^{\circ} 14^{\prime}$ and $30^{\circ} 43^{\prime}$ respectively. As seen in Table 5, the longitude given in Sūryasiddhānta is $199^{\circ} 0^{\prime}$, which is $14^{\circ} 51^{\prime}$ more than the relative longitude of $184^{\circ} 9^{\prime}$ in $A s^{\prime} v$ in̄i-beginning Krttikā system. The latitude given in Sūryasiddhānta is $37^{\circ} 0^{\prime}$, which is $6^{\circ} 17^{\prime}$ greater than the J2000.0 ecliptic latitude of $30^{\circ} 43^{\prime}$ of Arcturus. The ecliptic longitude of Arcturus is within one degree of the ecliptic longitude of Spica, the yogatārā of nakșatra Citrā. According to Süryasiddhānta, the difference in longitudes of the yogatārās of Citrā and Swāti is $19^{\circ} 0^{\prime}$. Thus Arcturus is not a good fit to be the yogatārā of Swāti. There is another star, Alphecca, which fits the longitude of the yogatārā of Swāti better. Alphecca $(\alpha \mathrm{CrB})$ has apparent magnitude of 2.20 and J2000.0 ecliptic longitude and latitude of $222^{\circ} 18^{\prime}$ and $44^{\circ} 19^{\prime}$ respectively. In terms of latitude, Alphecca is approximately $7^{\circ}$ higher and Arcturus is approximately $7^{\circ}$ lower. The relative longitude of Alphecca is $202^{\circ} 5^{\prime}$ in Aśvini-beginning Krttikā system, which is $3^{\circ} 5^{\prime}$ greater than the longitude of $199^{\circ} 0^{\prime}$ given in Sūryasiddhānta. The longitude matches well with $A s$ vinībeginning Krttikā offset value of $198^{\circ} 45^{\prime}$. Thus, Alphecca is a much better match in terms of longitude compared to Arcturus.

\subsection{The yogatārā of Uttarāṣāọhā}

Currently accepted yogatārā of Uttarāṣā Sgr) with apparent magnitude of 2.05 and J2000.0 eclip- tic longitude and latitude of $282^{\circ} 23$ and $-3^{\circ} 27^{\prime}$ respectively. As seen in Table 5, the longitude given in Sūryasiddhānta is $260^{\circ} 0^{\prime}$, which is $2^{\circ} 23^{\prime}$ lesser than the relative longitude of $262^{\circ} 23^{\prime}$ in Aśvinī-beginning Krttikā system. Latitude given in Sūryasiddhānta is $-5^{\circ} 0^{\prime}$, which is $1^{\circ} 33^{\prime}$ lesser than the $\mathrm{J} 2000.0$ ecliptic latitude of $-3^{\circ} 27^{\prime}$ of Nunki ( $\sigma$ Sgr). There is a star in the vicinity that fits the longitude and latitude given in Süryasiddhānta better than Nunki ( $\sigma$ Sgr). The star Namalsadirah I ( $\phi$ Sgr) has apparent magnitude of 3.15 and J2000.0 ecliptic longitude and latitude of $280^{\circ} 11^{\prime}$ and $-3^{\circ} 57^{\prime}$ respectively. It has relative longitude of $260^{\circ} 10^{\prime}$ in Aśvinī-beginning Krttik $\bar{a}$ system, which is an excellent match with the $260^{\circ} 0^{\prime}$ longitude given in Süryasiddhānta. Since Namalsadirah I ( $\phi$ Sgr) is a better fit in terms of both longitude and latitude compared to Nunki ( $\sigma$ Sgr), Namalsadirah I ( $\phi$ Sgr) has a better claim to be the yogatārā of Uttarāṣā

\subsection{The yogatārā of Dhanișțhā}

The accepted yogatārā of Dhanișthā is Rotanev ( $\beta$ Del) with apparent magnitude of 4.10 and J2000.0 ecliptic longitude and latitude of $316^{\circ} 20^{\prime}$ and $31^{\circ} 55^{\prime}$ respectively. As seen in Table 5, the longitude given in Süryasiddhānta is $290^{\circ} 0^{\prime}$, which is $6^{\circ} 23^{\prime}$ lesser than the relative longitude of $296^{\circ} 23^{\prime}$ of Rotanev ( $\beta$ Del) in Aśvinī-beginning Krttikā system. Latitude given in Sūryasiddhānta is $36^{\circ} 0^{\prime}$, which is $4^{\circ} 5$ greater than the $\mathrm{J} 2000.0$ ecliptic latitude of $31^{\circ} 55^{\prime}$ of Rotanev ( $\beta$ Del). There is a star in the vicinity that fits the longitude and latitude given in Süryasiddhānta better than Rotanev ( $\beta$ Del). The star Al Salib ( $\gamma 2$ Del) has apparent magnitude of 4.25 and J2000.0 ecliptic longitude and latitude of $319^{\circ} 22^{\prime}$ and $32^{\circ} 42^{\prime}$ respectively. It has relative longitude of $289^{\circ} 57^{\prime}$ in Aśvinī-beginning Rohiṇī system, which is an excellent match with the $290^{\circ} 0^{\prime}$ longitude given in Sūryasiddhānta. Since Al Salib ( $\gamma 2 \mathrm{Del})$ is a better fit in terms of both longitude and latitude compared to Rotanev ( $\beta$ Del), Al Salib ( $\gamma 2$ Del) has a better claim of being the yogatārā of Dhanișthā.

Based on the reassessment of the identifications of yogatārās above, alternative identifications of six yogatārās have been proposed. Table 6 shows the J2000.0 ecliptic coordinates of these six yogatārās along with the longitudes given in Sūryasiddhānta. The ecliptic coordinates of other yogatārās along with the longitudes given in Sūryasiddhānta have been listed in Table 2. As pointed above, the longitudes given in Sūryasiddhānta have some 
Table 6 Yogatārā identifications different than Burgess (1860).

\begin{tabular}{|c|c|c|c|c|c|c|}
\hline No. & Nakșatra & $\begin{array}{l}\text { Junction-star } \\
(\text { yogatārā })\end{array}$ & $\begin{array}{c}\text { Ecliptic } \\
\text { longitude }^{\mathrm{a}}\end{array}$ & $\begin{array}{l}\text { Dhruvaka } \\
\text { (longitude) }\end{array}$ & $\begin{array}{l}\text { Ecliptic } \\
\text { latitude }^{\mathrm{a}}\end{array}$ & $\begin{array}{c}\text { Vikșepa } \\
\text { (latitude) }\end{array}$ \\
\hline 1 & Aśvinī & $\operatorname{Sheratan}(\beta \text { Ari })^{\mathrm{b}}$ & $33^{\circ} 58^{\prime}$ & $8^{\circ} 0^{\prime}$ & $8^{\circ} 29^{\prime} \mathrm{N}$ & $10^{\circ} 0^{\prime} \mathrm{N}$ \\
\hline 1 & Aśvinī & Hamal $(\alpha \text { Ari })^{\mathrm{c}}$ & $37^{\circ} 40^{\prime}$ & $8^{\circ} 0^{\prime}$ & $9^{\circ} 58^{\prime}$ & $10^{\circ} 0^{\prime} \mathrm{N}$ \\
\hline 2 & Bharaṇī & Barani II (35 Ari) ${ }^{b}$ & $46^{\circ} 56^{\prime}$ & $20^{\circ} 0^{\prime}$ & $11^{\circ} 19^{\prime} \mathrm{N}$ & $12^{\circ} 0^{\prime} \mathrm{N}$ \\
\hline 2 & Bharaṇ̄ & Bharani $(41 \text { Ari) })^{\mathrm{c}}$ & $48^{\circ} 12^{\prime}$ & $20^{\circ} 0^{\prime}$ & $10^{\circ} 27^{\prime} \mathrm{N}$ & $12^{\circ} 0^{\prime} \mathrm{N}$ \\
\hline 13 & Hasta & $\operatorname{Algorab}(\delta \mathrm{Crv})^{\mathrm{b}}$ & $193^{\circ} 27^{\prime}$ & $170^{\circ} 0^{\prime}$ & $12^{\circ} 12^{\prime} \mathrm{S}$ & $11^{\circ} 0^{\prime} \mathrm{S}$ \\
\hline 13 & Hasta & Gienah $(\gamma C r v)^{\mathrm{c}}$ & $190^{\circ} 44^{\prime}$ & $170^{\circ} 0^{\prime}$ & $14^{\circ} 30^{\prime} \mathrm{S}$ & $11^{\circ} 0^{\prime} \mathrm{S}$ \\
\hline 15 & Swāti & Arcturus $(\alpha \text { Boo })^{b}$ & $204^{\circ} 14^{\prime}$ & $199^{\circ} 0^{\prime}$ & $30^{\circ} 44^{\prime} \mathrm{N}$ & $37^{\circ} 0^{\prime} \mathrm{N}$ \\
\hline 15 & Swāti & Alphecca $(\alpha C r B)^{\mathrm{c}}$ & $222^{\circ} 18^{\prime}$ & $199^{\circ} 0^{\prime}$ & $44^{\circ} 19^{\prime} \mathrm{N}$ & $37^{\circ} 0^{\prime} \mathrm{N}$ \\
\hline 21 & Uttarāṣāḍhā & Nunki $(\sigma \text { Sgr })^{\mathrm{b}}$ & $282^{\circ} 23^{\prime}$ & $260^{\circ} 0^{\prime}$ & $3^{\circ} 27^{\prime} \mathrm{S}$ & $5^{\circ} 0^{\prime} \mathrm{S}$ \\
\hline 21 & Uttarāṣā & Namalsadirah $I(\phi S g r)^{\mathrm{c}}$ & $280^{\circ} 11^{\prime}$ & $260^{\circ} 0^{\prime}$ & $3^{\circ} 57^{\prime} \mathrm{S}$ & $5^{\circ} 0^{\prime} \mathrm{S}$ \\
\hline 24 & Dhanișthā & Rotanev $(\beta \text { Del })^{b}$ & $316^{\circ} 20^{\prime}$ & $290^{\circ} 0^{\prime}$ & $31^{\circ} 55^{\prime} \mathrm{N}$ & $36^{\circ} 0^{\prime} \mathrm{N}$ \\
\hline 24 & Dhanișthā & Al Salib $(\gamma 2 \mathrm{Del})^{\mathrm{c}}$ & $319^{\circ} 22^{\prime}$ & $290^{\circ} 0^{\prime}$ & $32^{\circ} 44^{\prime} \mathrm{N}$ & $36^{\circ} 0^{\prime} \mathrm{N}$ \\
\hline
\end{tabular}

a J2000.0 ecliptic coordinates based on Stellarium software.

b Identifications by Burgrss (1860).

c This Study.

coordinates from Aśvinī-beginning Rohịn̄ system, some coordinates from Aśvinī-beginning Krttikā system, and some coordinates resulting from corrections made due to confusion between Rohinī and Krttikā systems. A comparison of longitudes of yogatārās in these different systems is presented in Table 7 to show the best fit with the longitudes given in Süryasiddhānta.

Some researchers have used the best fit method to date Süryasiddhānta. Burgess (1860) had assumed a base year of $560 \mathrm{CE}$ for identifications of yogatārās. He then calculated the average error in longitudes of the yogatārās and came to the conclusion that the star coordinates given in Süryasiddhānta were measured around $490 \mathrm{CE}$. Abhyankar (1991) used a least square method to conclude that the best fit was obtained for $430 \mathrm{CE}$.

Pingree and Morrissey (1989) compared the star coordinates given in Süryasiddhānta with star coordinates in 400, 425, 450, 475 and $500 \mathrm{CE}$ and concluded that best fit was close to $425 \mathrm{CE}$. As discussed above, the longitudes given in Süryasiddhānta are inconsistent due to a mix up between different systems and therefore a best fit approach cannot be applied to determine the date of observations. Since some of the yogatārās fit the Aśvinī-beginning Rohinī system, which has zero longitude in $131 \mathrm{BCE}$, current list of coordinates was updated before c. 130 BCE. Since most of the yogatārās fit the Aśvinī-beginning Krttikā system, which has zero longitude in $563 \mathrm{CE}$, current list of coordinates was updated again before c. $560 \mathrm{CE}$. Since vernal equinox stays in a nakșatra for approximately 960 years, the updates could have taken place up to 960 years before these dates. As the original system, Rohin̄i system, has zero longitude in $3045 \mathrm{BCE}$, the original list of nakșatras was compiled in fourth millennium BCE.

Misidentification of the yogatārās has also been investigated by Abhyankar (1991) and Venkatachar (2014). Abhyankar (1991) identified the yogatārās of Bharaṇī as Bharani (41 Ari) instead of Barani II (35 Ari), Ārdrā as Alhena $(\gamma \mathrm{Gem})$ instead of Betelguese ( $\alpha$ Ori), Áśleșa as Minazal V ( $\eta$ Hya) instead of Minazal III ( $\epsilon$ Hya), Hasta as Gienah ( $\gamma$ Crv) instead of Algorab ( $\delta$ Crv), Viśākha as Zubenelgenubi ( $\alpha$ Lib) instead of HIP 74392 ( $\iota$ Lib), $A b$ - 
Table 7 Comparision of longitudes of yogatārās.

(a)

\begin{tabular}{|c|c|c|c|c|c|c|c|}
\hline & 1. Aśvin̄̄ & 2. Bharaṇī & 3. Krttikā & 4. Rohiṇ̄ & 5. Mrgaśirā & 6. $\bar{A} r d r \bar{a}$ & 7. Punarvasu \\
\hline & $\alpha A r i$ & 41 Ari & $\eta$ Tau & $\alpha \mathrm{Tau}$ & $\lambda$ Ori & $\alpha$ Ori & $\beta \mathrm{Gem}$ \\
\hline $\begin{array}{l}\text { Aśvinī beginning } \\
\text { Rohiṇ̄ system }\end{array}$ & $8^{\circ} 0^{\prime}$ & $18^{\circ} 36^{\prime}$ & $30^{\circ} 23^{\prime}$ & $40^{\circ} 23^{\prime}$ & $54^{\circ} 05^{\prime}$ & $59^{\circ} 07^{\prime}$ & $83^{\circ} 57^{\prime}$ \\
\hline $\begin{array}{l}\text { Aśvinī beginning } \\
\text { Kṛttikā system }\end{array}$ & $17^{\circ} 38^{\prime}$ & $28^{\circ} 13^{\prime}$ & $40^{\circ} 0^{\prime}$ & $49^{\circ} 46^{\prime}$ & $63^{\circ} 42^{\prime}$ & $68^{\circ} 45^{\prime}$ & $93^{\circ} 27^{\prime}$ \\
\hline $\begin{array}{l}\text { Aśvinī beginning } \\
\text { Krttikā offset }\end{array}$ & $14^{\circ} 18^{\prime}$ & $24^{\circ} 53^{\prime}$ & $36^{\circ} 40^{\prime}$ & $46^{\circ} 26^{\prime}$ & $60^{\circ} 22^{\prime}$ & $65^{\circ} 25^{\prime}$ & $90^{\circ} 07^{\prime}$ \\
\hline Sūryasiddhānta & $8^{\circ} 0^{\prime}$ & $20^{\circ} 0^{\prime}$ & $37^{\circ} 30^{\prime}$ & $49^{\circ} 30^{\prime}$ & $63^{\circ} 0^{\prime}$ & $67^{\circ} 20^{\prime}$ & $93^{\circ} 0^{\prime}$ \\
\hline Best fit & $\begin{array}{c}\text { Aśvinī } \\
\text { beginning } \\
\text { Rohiṇ̄ } \\
\text { system }\end{array}$ & $\begin{array}{c}\text { Aśvin̄̄ } \\
\text { beginning } \\
\text { Rohiṇī } \\
\text { system }\end{array}$ & $\begin{array}{c}\text { Aśvinī } \\
\text { beginning } \\
\text { Krttikā } \\
\text { offset }\end{array}$ & $\begin{array}{c}\text { Aśvinī } \\
\text { beginning } \\
\text { Krttikā } \\
\text { system }\end{array}$ & $\begin{array}{c}\text { Aśvin̄̄ } \\
\text { beginning } \\
\text { Krttikā } \\
\text { system }\end{array}$ & $\begin{array}{c}\text { Aśvinī } \\
\text { beginning } \\
\text { Krttikā } \\
\text { system }\end{array}$ & $\begin{array}{c}\text { Aśvinī } \\
\text { beginning } \\
\text { Krttikā } \\
\text { system }\end{array}$ \\
\hline Deviation & $0^{\circ} 0^{\prime}$ & $-1^{\circ} 24^{\prime}$ & $-0^{\circ} 50^{\prime}$ & $0^{\circ} 16^{\prime}$ & $0^{\circ} 42^{\prime}$ & $1^{\circ} 25^{\prime}$ & $0^{\circ} 27^{\prime}$ \\
\hline
\end{tabular}

(b)

\begin{tabular}{|c|c|c|c|c|c|c|c|}
\hline & 8. Pușya & 9. Āśleșā & 10. Maghā & $\begin{array}{c}11 . \\
\text { Pūrvaphālgunī }\end{array}$ & $\begin{array}{l}\text { 12. Uttara- } \\
\text { phālgunī }\end{array}$ & 13. Hasta & 14. Citrā \\
\hline & $\delta \mathrm{Cnc}$ & $\epsilon$ Hya & $\alpha$ Leo & $\delta$ Leo & $\beta$ Leo & $\gamma \mathrm{Crv}$ & $\alpha \operatorname{Vir}$ \\
\hline $\begin{array}{l}\text { Aśvinī } \\
\text { beginning } \\
\text { Rohiṇī system }\end{array}$ & $99^{\circ} 05^{\prime}$ & $102^{\circ} 55^{\prime}$ & $120^{\circ} 22^{\prime}$ & $131^{\circ} 31^{\prime}$ & $142^{\circ} 11^{\prime}$ & $161^{\circ} 17^{\prime}$ & $174^{\circ} 15^{\prime}$ \\
\hline $\begin{array}{l}\text { Aśvin̄̄ } \\
\text { beginning } \\
\text { Krttikā system }\end{array}$ & $108^{\circ} 42^{\prime}$ & $112^{\circ} 28^{\prime}$ & $129^{\circ} 56^{\prime}$ & $141^{\circ} 12^{\prime}$ & $151^{\circ} 45^{\prime}$ & $170^{\circ} 50^{\prime}$ & $180^{\circ} 32^{\prime}$ \\
\hline $\begin{array}{l}\text { Aśvin̄̄ } \\
\text { beginning } \\
\text { Krttikā offset }\end{array}$ & $105^{\circ} 22^{\prime}$ & $109^{\circ} 8^{\prime}$ & $126^{\circ} 36^{\prime}$ & $137^{\circ} 52^{\prime}$ & $148^{\circ} 25^{\prime}$ & $167^{\circ} 30^{\prime}$ & $180^{\circ} 32^{\prime}$ \\
\hline $\begin{array}{l}\text { Sūrya- } \\
\text { siddhānta }\end{array}$ & $106^{\circ} 0^{\prime}$ & $109^{\circ} 0^{\prime}$ & $129^{\circ} 0^{\prime}$ & $144^{\circ} 0^{\prime}$ & $155^{\circ} 0^{\prime}$ & $170^{\circ} 0^{\prime}$ & $180^{\circ} 0^{\prime}$ \\
\hline Best fit & $\begin{array}{c}\text { Aśvinī } \\
\text { beginning } \\
\text { Krrttika } \\
\text { offset }\end{array}$ & $\begin{array}{c}\text { Aśvin̄ } \\
\text { beginning } \\
\text { Krttikā } \\
\text { offset }\end{array}$ & $\begin{array}{c}\text { Aśvinī } \\
\text { beginning } \\
\text { Krttika } \\
\text { system }\end{array}$ & $\begin{array}{c}\text { Aśvinī } \\
\text { beginning } \\
\text { Krttikā } \\
\text { system }\end{array}$ & $\begin{array}{c}\text { Aśvinī } \\
\text { beginning } \\
\text { Krttika } \\
\text { system }\end{array}$ & $\begin{array}{c}\text { Aśvinī } \\
\text { beginning } \\
\text { Krttikā } \\
\text { system }\end{array}$ & $\begin{array}{c}\text { Aśvin̄̄ } \\
\text { beginning } \\
\text { Krttikā } \\
\text { offset }\end{array}$ \\
\hline Deviation & $-0^{\circ} 38^{\prime}$ & $0^{\circ} 8^{\prime}$ & $0^{\circ} 56^{\prime}$ & $-2^{\circ} 48^{\prime}$ & $-3^{\circ} 15^{\prime}$ & $0^{\circ} 50^{\prime}$ & $0^{\circ} 32^{\prime}$ \\
\hline
\end{tabular}


(c)

\begin{tabular}{|c|c|c|c|c|c|c|c|}
\hline & 15. Swāti & 16. Viśa $\bar{k} h \bar{a}$ & 17. Anurādhā & 18. Jyeșthā & 19. Mūla & $\begin{array}{c}20 . \\
P \bar{u} r v \bar{a} s \bar{a} d h \bar{a}\end{array}$ & $\begin{array}{c}21 . \\
\text { Uttarāạăạ̣hā }\end{array}$ \\
\hline & $\alpha C r B$ & $\iota \mathrm{Lib}$ & $\delta \mathrm{Sco}$ & $\delta \mathrm{Sco}$ & $\lambda \mathrm{Sco}$ & $\delta \mathrm{Sgr}$ & $\phi S g r$ \\
\hline $\begin{array}{l}\text { Aśvinī } \\
\text { beginning } \\
\text { Rohiṇī } \\
\text { system }\end{array}$ & $192^{\circ} 22^{\prime}$ & $201^{\circ} 25^{\prime}$ & $212^{\circ} 58^{\prime}$ & $220^{\circ} 10^{\prime}$ & $234^{\circ} 59^{\prime}$ & $244^{\circ} 57^{\prime}$ & $250^{\circ} 32^{\prime}$ \\
\hline $\begin{array}{l}\text { Aśvin̄̄ } \\
\text { beginning } \\
\text { Krttikā } \\
\text { system }\end{array}$ & $202^{\circ} 05^{\prime}$ & $211^{\circ} 01^{\prime}$ & $222^{\circ} 35^{\prime}$ & $229^{\circ} 46^{\prime}$ & $244^{\circ} 35^{\prime}$ & $254^{\circ} 34^{\prime}$ & $260^{\circ} 10^{\prime}$ \\
\hline $\begin{array}{l}\text { Aśvinī } \\
\text { beginning } \\
\text { Krttikā offset }\end{array}$ & $198^{\circ} 45^{\prime}$ & $207^{\circ} 41^{\prime}$ & $219^{\circ} 15^{\prime}$ & $226^{\circ} 26^{\prime}$ & $241^{\circ} 15^{\prime}$ & $251^{\circ} 14^{\prime}$ & $256^{\circ} 50^{\prime}$ \\
\hline $\begin{array}{l}\text { Sūrya- } \\
\text { siddhānta }\end{array}$ & $199^{\circ} 0^{\prime}$ & $213^{\circ} 0^{\prime}$ & $224^{\circ} 0^{\prime}$ & $229^{\circ} 46^{\prime}$ & $241^{\circ} 0^{\prime}$ & $254^{\circ} 0^{\prime}$ & $260^{\circ} 0^{\prime}$ \\
\hline Best fit & $\begin{array}{c}\text { Aśvinī } \\
\text { beginning } \\
\text { Krttikā } \\
\text { offset }\end{array}$ & $\begin{array}{c}\text { Aśvinī } \\
\text { beginning } \\
K r t t i k \bar{a} \\
\text { system }\end{array}$ & $\begin{array}{c}\text { Aśvinī } \\
\text { beginning } \\
\text { Krttikā } \\
\text { system }\end{array}$ & $\begin{array}{c}\text { Aśvinī } \\
\text { beginning } \\
K r t t i k \bar{a} \\
\text { system }\end{array}$ & $\begin{array}{c}\text { Aśvinī } \\
\text { beginning } \\
\text { Krttika } \\
\text { offset }\end{array}$ & $\begin{array}{c}\text { Aśvinī } \\
\text { beginning } \\
\text { Krttikā } \\
\text { system }\end{array}$ & $\begin{array}{c}\text { Aśvin̄̄ } \\
\text { beginning } \\
\text { Krttikā } \\
\text { system }\end{array}$ \\
\hline Deviation & $-0^{\circ} 15^{\prime}$ & $-1^{\circ} 59^{\prime}$ & $-1^{\circ} 25^{\prime}$ & $0^{\circ} 46^{\prime}$ & $0^{\circ} 15^{\prime}$ & $0^{\circ} 34^{\prime}$ & $0^{\circ} 10^{\prime}$ \\
\hline
\end{tabular}

(d)

\begin{tabular}{|c|c|c|c|c|c|c|c|}
\hline & 22. Abhijita & 23. Śravaṇa & 24. Dhanișthā & 25. Śatabhișaja & $\begin{array}{l}\text { 26. Pūrva- } \\
\text { bhādra- } \\
\text { padā }\end{array}$ & $\begin{array}{l}\text { 27. Uttara- } \\
\text { bhādra- } \\
\text { padā }\end{array}$ & 28. Revatī \\
\hline & $\alpha \operatorname{Lyr}$ & $\alpha \mathrm{Aql}$ & $\gamma 2 \mathrm{Del}$ & $\delta \mathrm{Aqr}$ & $\alpha$ Peg & $\gamma$ Peg & $\zeta$ Psc \\
\hline $\begin{array}{l}\text { Aśvinī } \\
\text { beginning } \\
\text { Rohinī } \\
\text { system }\end{array}$ & $255^{\circ} 40^{\prime}$ & $271^{\circ} 50^{\prime}$ & $289^{\circ} 57^{\prime}$ & $311^{\circ} 57^{\prime}$ & $323^{\circ} 57^{\prime}$ & $339^{\circ} 36^{\prime}$ & $350^{\circ} 12^{\prime}$ \\
\hline $\begin{array}{l}\text { Aśvinī } \\
\text { beginning } \\
\text { Krttikā } \\
\text { system }\end{array}$ & $265^{\circ} 18^{\prime}$ & $281^{\circ} 33^{\prime}$ & $299^{\circ} 31^{\prime}$ & $321^{\circ} 34^{\prime}$ & $333^{\circ} 32^{\prime}$ & $349^{\circ} 12^{\prime}$ & $359^{\circ} 50^{\prime}$ \\
\hline $\begin{array}{l}\text { Aśvinī } \\
\text { beginning } \\
\text { Krttik } \bar{a} \\
\text { offset }\end{array}$ & $261^{\circ} 58^{\prime}$ & $278^{\circ} 13^{\prime}$ & $296^{\circ} 11^{\prime}$ & $318^{\circ} 14^{\prime}$ & $330^{\circ} 12^{\prime}$ & $345^{\circ} 52^{\prime}$ & $356^{\circ} 30^{\prime}$ \\
\hline $\begin{array}{l}\text { Sürya- } \\
\text { siddhānta }\end{array}$ & $266^{\circ} 40^{\prime}$ & $280^{\circ} 0^{\prime}$ & $290^{\circ} 0^{\prime}$ & $320^{\circ} 0^{\prime}$ & $326^{\circ} 0^{\prime}$ & $337^{\circ} 0^{\prime}$ & $359^{\circ} 50^{\prime}$ \\
\hline Best fit & $\begin{array}{c}\text { Aśvinī } \\
\text { beginning } \\
\text { Krttikā } \\
\text { system }\end{array}$ & $\begin{array}{c}\text { Aśvinī } \\
\text { beginning } \\
\text { Krttikā } \\
\text { system }\end{array}$ & $\begin{array}{c}\text { Aśvinī } \\
\text { beginning } \\
\text { Rohiṇ̄ } \\
\text { system }\end{array}$ & $\begin{array}{c}\text { Aśvinī } \\
\text { beginning } \\
\text { Krttikā } \\
\text { system }\end{array}$ & $\begin{array}{c}\text { Aśvinī } \\
\text { beginning } \\
\text { Rohiṇ̄ } \\
\text { system }\end{array}$ & $\begin{array}{c}\text { Aśvinī } \\
\text { beginning } \\
\text { Rohiṇī } \\
\text { system }\end{array}$ & $\begin{array}{c}\text { Aśvinī } \\
\text { beginning } \\
\text { Krttika } \\
\text { system }\end{array}$ \\
\hline Deviation & $-1^{\circ} 22^{\prime}$ & $1^{\circ} 33^{\prime}$ & $-0^{\circ} 3^{\prime}$ & $1^{\circ} 34^{\prime}$ & $-2^{\circ} 3^{\prime}$ & $2^{\circ} 36^{\prime}$ & $0^{\circ} 0^{\prime}$ \\
\hline
\end{tabular}


hijīt as Altair ( $\alpha$ Aql) instead of Vega ( $\alpha$ Lyr), Śravaṇa as Rotanev ( $\beta$ Del) instead of Altair ( $\alpha$ Aql), Dhanișthā as Sadalsuud ( $\beta$ Aqr) instead of Rotanev ( $\beta$ Del), and Śatabhișaja as Fomalhaut ( $\alpha$ PsA) instead of Hydor ( $\lambda$ Aqr). These identifications of alternative stars as the yogatārās have been justified based on the accepted yogatārās not being within their boundaries or being too far away from ecliptic. Both of these reasons are unjustified. Many yogatārās are outside their boundaries in uniform division of ecliptic because the original span of nakșatras was not uniform. This will be discussed in detail in a future paper. There was no constraint on yogatārās to be close to ecliptic, which is evident from the latitudes of many yogatārās being over 20 degrees. Also, many of these identifications completely disregard the latitudes given in Sūryasiddhānta, and hence are unacceptable. Venkatachar (2014) has also proposed alternative identifications of yogatārās and justified the identifications based on the accepted yogatārās not being within their boundaries. This reasoning, as discussed above, is unjustified. Similar to Abhyankar (1991), many of these identifications completely disregard the latitudes given in Sūryasiddhānta, and hence are unacceptable.

\section{Conclusions}

(i) Contrary to accepted view that Indian astronomers were using polar coordinates, Indian astronomers were using sidereal ecliptic coordinates, which does not change with time to a significant extent. (ii) Indian astronomers had developed precise nakșatra boundaries with zero points at the yogatārās of Rohiṇ̄ and Krttikāa. (iii) The origin of the nakșatra system can be traced to 4th millennium BCE. (iv) The star positions given in Sūryasiddhānta are an extrapolation of the earlier sidereal ecliptic longitudes after applying correction for the change in zero point due to shift of equinox. (v) The star positions based on zero points corresponding to two different epochs seem to have been mixed up. The coordinates given in astronomical texts are a mix of coordinates from Rohiṇi and Krttikā systems. This would imply that an earlier Indian tradition of making observations of star coordinates was lost by the time of Sūryasiddhānta. (vi) Some of the yogatārās have been misidentified. Most importantly, the yogatārā of Aśvinī is Hamal ( $\alpha$ Ari) instead of Sher$\operatorname{atan}(\beta$ Ari).

\section{Acknowledgement}

Financial support received from the Federation of Jain Associations in North America (JAINA) is gratefully acknowledged. Author would also like to thank Dr. Manish Mehta, Dr. Sulekh Jain and Dr. Shugan Jain for their comments and encouragement. Additionally, author would like to thank one of the reviewers for pointing out that Sūryasiddhānta uses ecliptic coordinates for its planetary model and it would not make sense for Süryasiddhānta to use polar coordinates for star positions.

\section{Bibliography}

[1] Abhyankar, K. D. Misidentification of some Indian nakșatras, Indian Journal of History of Science, 26.1 (1991): 1-10.

[2] Burgess, E. Translation of the Surya-Siddhanta: A Text Book of Hindu Astronomy, with Notes, and an Appendix, Journal of the American Oriental Society, 6 (1860): 141-498.

[3] Pingree, D. and Morrissey, P. On the Identification of the Yogatārās of the Indian nakșatras, Journal for the History of Astronomy, 20. 2 (1989): 99-119.

[4] Simhha, U. N. Sūryasiddhānta with Hindi translation and extensive Introduction, Śrīmatī Savitrī Devī Bāgadia Trust, Kolkata, 1986.

[5] Śrīvāstava, M. P. Sūryasiddhānta, with scientific commentary, Dr. Ratnakumarī Swādhyāya Saṃsthāna, Allahabad, 1982.

[6] Venkatachar, M. A. Yogataaras, their Misidentifications and Corrective Measures, 2014. https://astronomyrevisitedbymav.files. wordpress.com/2017/06/yoga-final-withfigures-date.pdf 